Cochrane Database of Systematic Reviews

\title{
Single dose oral ibuprofen plus caffeine for acute postoperative pain in adults (Review)
}

Derry S, Wiffen PJ, Moore RA

Derry S, Wiffen PJ, Moore RA.

Single dose oral ibuprofen plus caffeine for acute postoperative pain in adults.

Cochrane Database of Systematic Reviews 2015, Issue 7. Art. No.: CD011509.

DOI: 10.1002/14651858.CD011509.pub2. 
TABLE OF CONTENTS

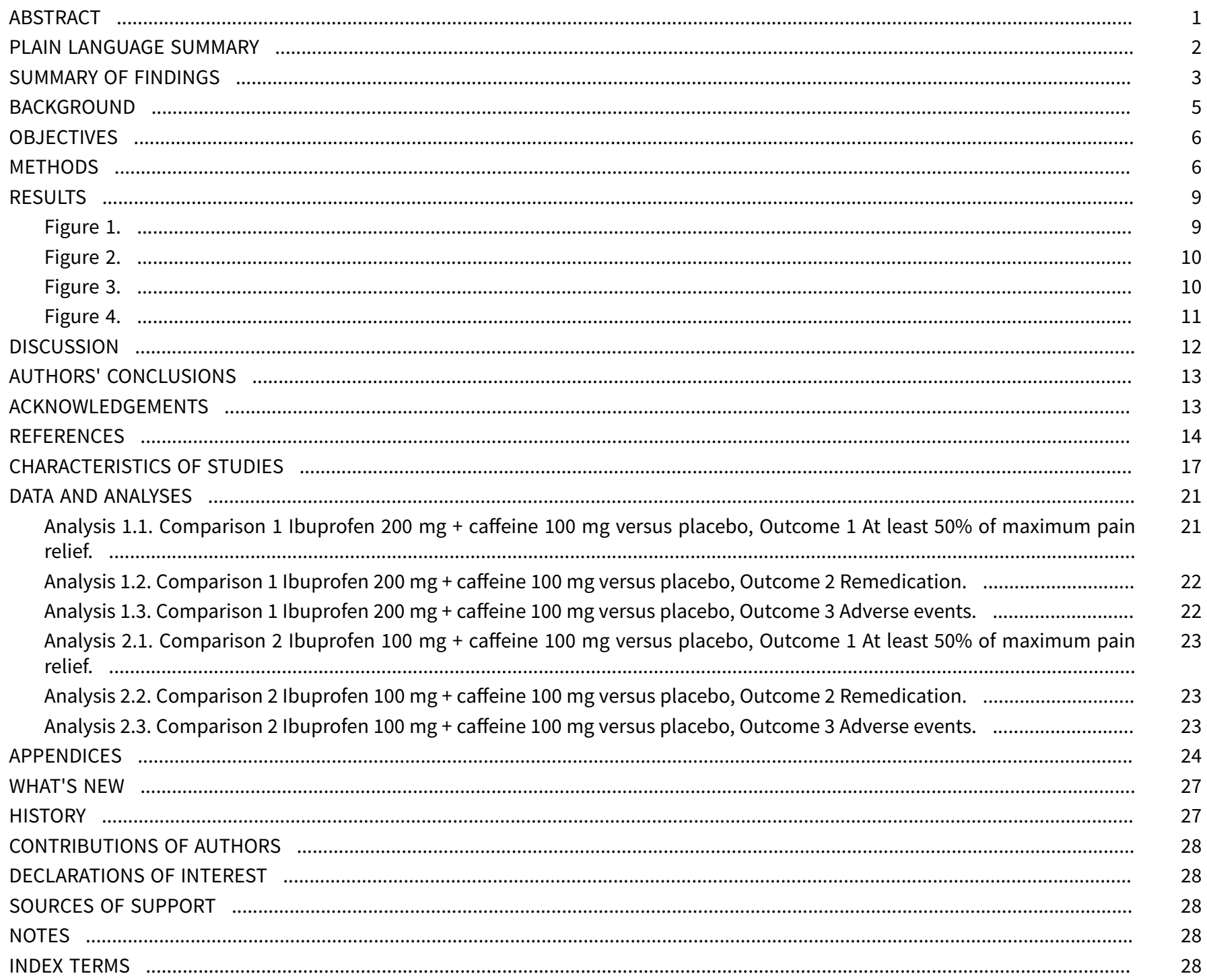


[Intervention Review]

\section{Single dose oral ibuprofen plus caffeine for acute postoperative pain in adults}

Sheena Derry¹, Philip J Wiffen², R Andrew Moore ${ }^{3}$

1Oxford, UK. 2Thame, UK. 3Plymouth, UK

Contact: Sheena Derry, Oxford, Oxfordshire, UK. sheena.derry@retired.ox.ac.uk.

Editorial group: Cochrane Pain, Palliative and Supportive Care Group.

Publication status and date: Stable (no update expected for reasons given in 'What's new'), published in Issue 5, 2019.

Citation: Derry S, Wiffen PJ, Moore RA. Single dose oral ibuprofen plus caffeine for acute postoperative pain in adults. Cochrane Database of Systematic Reviews 2015, Issue 7. Art. No.: CD011509. DOI: 10.1002/14651858.CD011509.pub2.

Copyright @ 2019 The Cochrane Collaboration. Published by John Wiley \& Sons, Ltd.

\section{A B S T R A C T}

\section{Background}

There is good evidence that combining two different analgesics in fixed doses in a single tablet can provide better pain relief in acute pain and headache than either drug alone, and that the drug-specific benefits are essentially additive. This appears to be broadly true in postoperative pain and migraine headache across a range of different drug combinations, and when tested in the same and different trials. Adding caffeine to analgesics also increases the number of people obtaining good pain relief. Combinations of ibuprofen and caffeine are available without prescription in some parts of the world.

\section{Objectives}

To assess the analgesic efficacy and adverse effects of a single oral dose of ibuprofen plus caffeine for moderate to severe postoperative pain, using methods that permit comparison with other analgesics evaluated in standardised trials using almost identical methods and outcomes.

\section{Search methods}

We searched the Cochrane Central Register of Controlled Trials (CENTRAL), MEDLINE, EMBASE, the Oxford Pain Relief Database, two clinical trial registries, and the reference lists of articles. The date of the most recent search was 1 February 2015.

\section{Selection criteria}

Randomised, double-blind, placebo- or active-controlled clinical trials of single dose oral ibuprofen plus caffeine for acute postoperative pain in adults.

\section{Data collection and analysis}

Two review authors independently considered trials for inclusion in the review, assessed risk of bias, and extracted data. We used the area under the pain relief versus time curve to derive the proportion of participants with at least $50 \%$ pain relief over six hours prescribed either ibuprofen plus caffeine or placebo. We calculated the risk ratio (RR) and number needed to treat to benefit (NNT). We used information on the use of rescue medication to calculate the proportion of participants requiring rescue medication and the weighted mean of the median time to use. We also collected information on adverse effects.

\section{Main results}

We identified five randomised, double-blind studies with 1501 participants, but only four had been published and had relevant outcome data. These four studies were of high quality, although two of the studies were small. 
Both ibuprofen $200 \mathrm{mg}$ + caffeine $100 \mathrm{mg}$ and ibuprofen $100 \mathrm{mg}$ + caffeine $100 \mathrm{mg}$ produced significantly more participants than placebo who achieved at least $50 \%$ of maximum pain relief over six hours, and both doses significantly reduced remedication rates (moderate quality evidence). For at least 50\% of maximum pain relief, the NNT was 2.1 (95\% confidence interval 1.8 to 2.5 ) for ibuprofen $200 \mathrm{mg}+$ caffeine $100 \mathrm{mg}$ (four studies, 334 participants) and 2.4 (1.9 to 3.1) for ibuprofen $100 \mathrm{mg}+$ caffeine $100 \mathrm{mg}$ (two studies, 200 participants) (moderate quality evidence). These values were close to those predicted by published models for combination analgesics in acute pain, and were supported by low (good) NNT values for prevention of remedication.

Adverse event rates were low, and no sensible analysis was possible.

\section{Authors' conclusions}

For ibuprofen $200 \mathrm{mg}$ + caffeine $100 \mathrm{mg}$ particularly, the low NNT value is among the lowest (best) values for analgesics in this pain model. The combination is not commonly available, but can be probably be achieved by taking a single 200 mg ibuprofen tablet with a cup of modestly strong coffee or caffeine tablets. In principle, this can deliver good analgesia at lower doses of ibuprofen.

\section{PLAIN LANGUAGE SUMMARY}

\section{Single dose oral ibuprofen plus caffeine for acute postoperative pain in adults}

Acute pain is often felt soon after injury. Most people who have surgery have moderate or severe pain afterwards. Painkillers (analgesics) are tested in people with pain, often following the removal of wisdom teeth. This pain is usually treated with painkillers taken by mouth. Results can be applied to other forms of acute pain.

A series of Cochrane reviews looks at how good painkillers are. We know that in some circumstances combining different painkillers in the same tablet or taking separate tablets at the same time gives good pain relief to more people than either painkiller alone. This is particularly true using a combination of two painkillers that work by different mechanisms. This review looked at how good the combination of ibuprofen and caffeine was in relieving moderate or severe pain after surgery.

We searched up to 1 February 2015 and found four studies with a maximum of 334 participants with information for analysis. Ibuprofen $200 \mathrm{mg}$ plus caffeine $100 \mathrm{mg}$ provided effective pain relief for 6 in 10 (59\%) participants, compared with 1 in 10 (11\%) participants with placebo (moderate quality evidence).

Adverse events occurred at similar rates with the ibuprofen plus caffeine combination and placebo in these single dose studies (low quality evidence). No serious adverse events or withdrawals due to adverse events occurred with the combination.

The combination of ibuprofen $200 \mathrm{mg}+$ caffeine $100 \mathrm{mg}$ is not commonly available, but can probably be achieved by taking a single $200 \mathrm{mg}$ ibuprofen tablet with a cup of modestly strong coffee. Common sources of caffeine include not only caffeine tablets (100 mg is sufficient), but coffee (100 mg to $150 \mathrm{mg}$ per mug or cup with a volume of about $240 \mathrm{~mL}$ or $8 \mathrm{fl} \mathrm{oz}$, or a double espresso), but also tea ( $75 \mathrm{mg}$ per mug), cola drinks (up to $40 \mathrm{mg}$ per drink), energy drinks (approximately $80 \mathrm{mg}$ per drink), plain chocolate (up to $50 \mathrm{mg}$ per bar), and caffeine tablets (100 mg per tablet).

Some people may get good levels of pain relief with a lower dose of ibuprofen when the ibuprofen is combined with caffeine. 


\section{SUMMARY OF FINDINGS}

\section{Summary of findings for the main comparison.}

Ibuprofen plus caffeine compared with placebo for moderate to severe acute postoperative pain in adults

Patient or population: Adults with acute pain

\section{Settings: Hospital or community}

Intervention: Oral ibuprofen $200 \mathrm{mg}+$ caffeine $100 \mathrm{mg}$

\section{Comparison: Oral placebo}

\begin{tabular}{|c|c|c|c|c|c|c|}
\hline \multirow[t]{2}{*}{ Outcomes } & \multicolumn{2}{|c|}{ Probable outcome with } & \multirow{2}{*}{$\begin{array}{l}\text { Relative effect and NNT } \\
\text { or NNH } \\
(95 \% \mathrm{Cl})\end{array}$} & \multirow{2}{*}{$\begin{array}{l}\text { Number of studies, partici- } \\
\text { pants, events }\end{array}$} & \multirow{2}{*}{$\begin{array}{l}\text { Quality of the } \\
\text { evidence } \\
\text { (GRADE) }\end{array}$} & \multirow[t]{2}{*}{ Comments } \\
\hline & Comparator & Intervention & & & & \\
\hline $\begin{array}{l}\text { At least } 50 \% \text { of maximum } \\
\text { pain relief over } 4 \text { to } 6 h\end{array}$ & 100 in 1000 & 590 in 1000 & $\begin{array}{l}\text { RR } \\
5.5 \text { (3.5 to } 8.7) \\
\text { NNT } \\
2.1 \text { (1.8 to } 2.5)\end{array}$ & $\begin{array}{l}4 \text { studies } \\
334 \text { participants } \\
119 \text { events }\end{array}$ & Moderate & $\begin{array}{l}\text { Number of events } \\
\text { below } 200\end{array}$ \\
\hline $\begin{array}{l}\text { Participants remedicating } \\
\text { within } 8 \text { hours }\end{array}$ & 600 in 1000 & 260 in 1000 & $\begin{array}{l}\text { RR } \\
0.5 \text { ( } 0.4 \text { to } 0.6) \\
\text { NNTp } \\
2.9 \text { ( } 2.2 \text { to } 4.3)\end{array}$ & $\begin{array}{l}3 \text { studies } \\
293 \text { participants } \\
128 \text { events }\end{array}$ & Moderate & $\begin{array}{l}\text { Number of events } \\
\text { below } 200\end{array}$ \\
\hline $\begin{array}{l}\text { Participants with a serious } \\
\text { adverse event }\end{array}$ & No serious adv & e events & & $\begin{array}{l}4 \text { studies } \\
336 \text { participants } \\
0 \text { events }\end{array}$ & Low & $\begin{array}{l}\text { Studies underpow- } \\
\text { ered to detect these } \\
\text { events }\end{array}$ \\
\hline
\end{tabular}

GRADE Working Group grades of evidence 
High quality: Further research is very unlikely to change our confidence in the estimate of effect.

Moderate quality: Further research is likely to have an important impact on our confidence in the estimate of effect and may change the estimate.

Low quality: Further research is very likely to have an important impact on our confidence in the estimate of effect and is likely to change the estimate.

Very low quality: We are very uncertain about the estimate.

NNH: number needed to harm; NNT: number needed to treat; NNTp: number needed to treat to prevent an event; RR: risk ratio 


\section{B A C K G R O U N D}

This is one of a series of reviews whose aim is to increase awareness of the range of analgesics that are potentially available, and present evidence for relative analgesic efficacy through indirect comparisons with placebo, in very similar trials performed in a standard manner, with very similar outcomes, and over the same duration. Such relative analgesic efficacy does not in itself determine choice of drug for any situation or patient, but guides policy-making at the local level. The series covers all analgesics licensed for acute postoperative pain in the UK, and dipyrone, which is commonly used in Spain, Portugal, and Latin American countries. The results have been examined in an overview (Moore 2011a), and important individual reviews include ibuprofen (Derry 2009), codeine (Derry 2010), paracetamol (Toms 2008), and etoricoxib (Clarke 2012), and combinations of ibuprofen with paracetamol (Derry 2013a), codeine (Derry 2013b), and oxycodone (Derry 2013c). Knowing the relative efficacy of different analgesic drugs at various doses can be helpful.

\section{Description of the condition}

Acute pain occurs as a result of tissue damage either accidentally due to an injury or as a result of surgery. Acute postoperative pain is a manifestation of inflammation due to tissue injury or nerve injury, or both. The management of postoperative pain and inflammation is a critical component of patient care.

\section{Description of the intervention}

\section{Acute pain trials}

Single dose trials in acute pain are commonly short in duration, rarely lasting longer than 12 hours. The numbers of participants are small, allowing no reliable conclusions to be drawn about safety. To show that the analgesic is working, it is necessary to use placebo (McQuay 2005). There are clear ethical considerations in doing this. These ethical considerations are answered by using acute pain situations where the pain is expected to go away, and by providing additional analgesia, commonly called rescue analgesia, if the pain has not diminished after about an hour. This is reasonable, because not all participants given an analgesic will have significant pain relief. Approximately $18 \%$ of participants given placebo will have significant pain relief (Moore 2006), and up to $50 \%$ may have inadequate analgesia with active medicines. The use of additional or rescue analgesia is hence important for all participants in the trials.

Clinical trials measuring the efficacy of analgesics in acute pain have been standardised over many years (McQuay 2012). Trials have to be randomised and double-blind. Typically, in the first few hours or days after an operation, patients develop pain that is moderate to severe in intensity, and will then be given the test analgesic or placebo. Pain is measured using standard pain intensity scales immediately before the intervention, and then using pain intensity and pain relief scales over the following four to six hours for shorter-acting drugs, and up to 12 or 24 hours for longer-acting drugs. Pain relief of half the maximum possible pain relief or better (at least $50 \%$ pain relief) is typically regarded as a clinically useful outcome. For patients given rescue medication it is usual for no additional pain measurements to be made, and for all subsequent measures to be recorded as initial pain intensity or baseline (zero) pain relief (baseline observation carried forward). This process ensures that analgesia from the rescue medication is not wrongly ascribed to the test intervention. In some trials the last observation is carried forward, which gives an inflated response for the test intervention compared to placebo, but the effect has been shown to be negligible over four to six hours (Moore 2005). Patients usually remain in the hospital or clinic for at least the first six hours following the intervention, with measurements supervised, although they may then be allowed home to make their own measurements in trials of longer duration.

\section{Ibuprofen}

Ibuprofen is a nonsteroidal anti-inflammatory drug (NSAID). It was developed in the 1960s and is used extensively throughout the world for relief of pain and inflammation in both acute and chronic conditions. It is available over the counter in most countries, usually as $200 \mathrm{mg}$ tablets, with $1200 \mathrm{mg}$ as the recommended maximum daily dose for adults. Under medical supervision, up to $3200 \mathrm{mg}$ daily may be taken, divided into three doses. Soluble salts of ibuprofen have better efficacy (Derry 2009). A major concern regarding the use of conventional NSAIDs postoperatively is the possibility of bleeding from both the operative site (because of the inhibition of platelet aggregation) (Forrest 2002), and from the upper gastrointestinal tract, (especially in patients stressed by surgery, the elderly, frail, or dehydrated). Other potentially serious adverse events include acute liver injury, acute renal injury, heart failure, and adverse reproductive outcomes (Hernandez-Diaz 2001). However, such complications are more likely to occur with chronic use, and NSAIDs generally present fewer risks if used in the short-term, as in the treatment of postoperative pain (Rapoport 1999).

\section{Caffeine}

Caffeine is a naturally occurring compound found in the seeds, leaves, and fruit of many plants, where it is thought to function as a natural pesticide. It has a long (at least 5000 years) history of human consumption in the form of beverages such as tea and coffee, and foodstuffs such as chocolate. Caffeine intake varies widely among individuals and populations, but can be broadly divided into low (< $100 \mathrm{mg}$ per day), moderate (100 mg to $400 \mathrm{mg}$ per day), and high intake ( $>400 \mathrm{mg}$ per day), with the majority of people falling within the moderate intake range. Common sources of caffeine today include coffee (100 mg to $150 \mathrm{mg}$ per mug or cup with a volume of about $240 \mathrm{~mL}$ or $8 \mathrm{fl} \mathrm{oz}$, or a double espresso), tea ( $75 \mathrm{mg}$ per mug), cola drinks (up to $40 \mathrm{mg}$ per drink), energy drinks (approximately $80 \mathrm{mg}$ per drink), plain chocolate (up to $50 \mathrm{mg}$ per bar), and caffeine tablets (100 mg per tablet). Some 'high-energy' drinks have the caffeine content of five or six mugs of coffee. Caffeine tablets are also available, usually as $100 \mathrm{mg}$ or $200 \mathrm{mg}$ tablets.

Caffeine is a methylxanthine that is known to act as a central nervous system stimulant. It has a wide range of physiological effects in humans (Sawynok 1993) including increased wakefulness, alertness, endurance, heart rate, and blood pressure, and is regarded as a psychostimulant (enhances mood; Donovan 2001).

\section{How the intervention might work}

Clinicians prescribe NSAIDs on a routine basis for a range of mild, moderate, and severe pain. NSAIDs are the most commonly prescribed analgesic medications worldwide, and their efficacy for treating acute pain has been well demonstrated (Moore 2003). They reversibly inhibit cyclooxygenase (prostaglandin endoperoxide 
synthase), the enzyme mediating production of prostaglandins and thromboxane A2 (FitzGerald 2001). Prostaglandins mediate a variety of physiological functions such as maintenance of the gastric mucosal barrier, regulation of renal blood flow, and regulation of endothelial tone. They also play an important role in inflammatory and nociceptive processes. Ibuprofen, like most NSAIDs, causes reversible inhibition of the cyclooxygenases, which interferes with thromboxane and prostaglandin synthesis, and increases production of anti-inflammatory lipoxins.

Using combinations of analgesics works well in acute pain, as results are additive (Moore 2012). Combinations of ibuprofen and other analgesics have been shown to be particularly effective in acute pain, with low (good) number needed to treat for an additional beneficial outcome (NNT) values compared with placebo (Derry 2013a; Derry 2013b; Derry 2013c) for levels of benefit patients think useful (Moore 2013).

Caffeine is not thought to be an analgesic when used alone, but it has been added to various analgesics for many years in the belief that it enhances analgesic effect (Sawynok 2011a; Sawynok 2011b). A Cochrane review demonstrated a $10 \%$ increase in participants experiencing good levels of pain relief when $100 \mathrm{mg}$ caffeine was added to a standard dose of common analgesics such as paracetamol and ibuprofen (Derry 2014). Caffeine has been shown to potentiate the effects of ibuprofen in animal models (Lopez 2006). The mechanisms by which caffeine may contribute to, or enhance the efficacy of other analgesics are not well understood. It is known to be a competitive antagonist of adenosine $A_{1}$ and $A_{2}$ receptors at plasma concentrations observed through normal dietary caffeine intake (in the $10 \mu \mathrm{M}$ to $100 \mu \mathrm{M}$ range). Many of the putative mechanisms of action are thought of in terms of this disruption of normal adenosine signalling. Proposed mechanisms of action include (Renner 2007; Sawynok 1993; Zhang 2001):

- improved drug absorption through lower gastric $\mathrm{pH}$ and increased gastric blood flow;

- reduced metabolic clearance of drugs through reduced hepatic blood flow;

- blockade of peripheral pro-nociceptive adenosine signalling, and activation of the central noradenosine pathway (painsuppressing systems);

- transcriptional down-regulation of cyclooxygenase-2 (COX-2), via blockade of the adenosine $\mathrm{A}_{2 \mathrm{a}}$ receptor;

- relief of inhibitor adenosine actions on central cholinergic nerve terminals;

- changes in mood and emotional state contributing to changes in the perception of pain.

\section{Why it is important to do this review}

There are increasing concerns over the potential for people to ingest too much paracetamol without knowing it, resulting in repeated supratherapeutic ingestions of paracetamol, also described as 'staggered overdose'. The problem is greater with concomitant alcohol abuse (Craig 2012).

There are also increasing concerns about opioid use generally, and codeine in particular, with interest in reducing opioid exposure to the general public, especially in over the counter (OTC) medicines such as paracetamol plus codeine. The presence of widely different proportions of ultra-fast metabolisers of codeine in different communities complicates dose recommendations (ledema 2011).

Combinations of ibuprofen plus caffeine have been examined in acute pain conditions such as tension headache (Diamond 2000), and combinations of ibuprofen and caffeine are available in some parts of the world, particularly Central and South America.

Since the publication of the Cochrane review on caffeine as an analgesic adjuvant (Derry 2014), and another paper on analgesic combinations (Moore 2012) (both based on the single dose oral analgesic series from the Cochrane Library), caffeine has come to the fore as a possible alternative to opioids for analgesic combination.

\section{O B J E C T IVES}

To assess the analgesic efficacy and adverse effects of a single oral dose of ibuprofen plus caffeine for moderate to severe postoperative pain, using methods that permit comparison with other analgesics evaluated in standardised trials using almost identical methods and outcomes.

\section{METHOD S}

\section{Criteria for considering studies for this review}

\section{Types of studies}

We included double-blind studies of single dose oral ibuprofen plus caffeine compared with placebo for the treatment of moderate to severe postoperative pain in adults, with at least 10 participants randomly allocated to each treatment group. We included multiple dose studies if appropriate data from the first dose were available, and cross-over studies (provided that data from the first arm were presented separately).

We excluded:

- review articles, case reports, and clinical observations;

- studies of experimental pain;

- studies where pain relief was assessed only by clinicians, nurses, or carers (not patient-reported);

- studies of less than four hours duration or studies that failed to present data over four to six hours postdose.

For postpartum pain, we included studies if the pain investigated was due to episiotomy or Caesarean section, irrespective of the presence of uterine cramps; we excluded studies investigating pain due to uterine cramps alone.

We did not consider studies without a placebo group that compared only ibuprofen plus caffeine with the same dose of ibuprofen alone. The reason is that this comparison is considered across a number of different pain conditions in a separate review examining the analgesic adjuvant effect of caffeine in acute pain (Derry 2014).

\section{Types of participants}

We included studies of adult participants (15 years or older) with established postoperative pain of moderate to severe intensity following day surgery or in-patient surgery. For studies using a visual analogue scale (VAS), we considered that pain intensity of greater than $30 \mathrm{~mm}$ equated to pain of at least moderate intensity (Collins 1997). 


\section{Types of interventions}

Ibuprofen plus caffeine or matched placebo administered as a single oral dose for postoperative pain. The ibuprofen and caffeine may have been administered as separate tablets taken together, or in a combined tablet. We included all dose combinations.

\section{Types of outcome measures}

We collected the following data where available.

- Patient-reported pain at baseline (physician, nurse, or carerreported pain was not be included in the analysis).

- Patient-reported pain relief expressed at least hourly over four to six hours using validated pain scales (pain intensity or pain relief in the form of VAS or categorical scales, or both).

- Patient global assessment of efficacy (PGE), using a standard categorical scale.

- Time to use of rescue medication.

- Number of participants using rescue medication.

- Number of participants with one or more adverse event(s).

- Number of participants with serious adverse events.

- Number of withdrawals (all-cause, adverse events).

\section{Primary outcomes}

Participants achieving at least 50\% pain relief over four to six hours.

\section{Secondary outcomes}

1. Median (or mean) time to use of rescue medication.

2. Participants using rescue medication.

3. Participants with: any adverse event; any serious adverse event (as reported in the study); withdrawal due to an adverse event.

4. Other withdrawals: withdrawals for reasons other than lack of efficacy (participants using rescue medication).

\section{Search methods for identification of studies}

A previous Cochrane review had recently searched for studies of single dose oral of analgesics (including ibuprofen) plus caffeine in postoperative pain (Derry 2014). That review had analysed analgesics plus caffeine compared with analgesics without caffeine. Its principal aim was to establish the analgesic effect of added caffeine. It did not examine analgesics plus caffeine compared with placebo. We used results of searches for that review as well as additional searching strategies.

\section{Electronic searches}

We searched the following databases.

- The Cochrane Central Register of Controlled Trials (CENTRAL; 2015, Issue 1).

- MEDLINE (via Ovid) 1946 to 1 February 2015.

- EMBASE (via Ovid) 1974 to 1 February 2015.

- The Oxford Pain Relief Database (Jadad 1996a).

See Appendix 1 for the CENTRAL search strategy, Appendix 2 for the MEDLINE search strategy, and Appendix 3 for the EMBASE search strategy. We did not limit the searches by language.

\section{Searching other resources}

On 1 February 2015 we searched for additional studies in reference lists of retrieved articles and reviews. We also searched the ClinicalTrials database (www.clinicaltrials.gov) and the WHO International Clinical Trials Registry Platform (apps.who.int/trialsearch/) for otherwise unpublished trial results and information about ongoing studies.

We contacted Bayer Schering Pharma, the distributor of ActronPlus in Argentina and Actron Max in Mexico. No clinical trial data were available.

\section{Data collection and analysis}

\section{Selection of studies}

Two review authors independently assessed the search results and agreed on the studies to be included in the review. Disagreements would have been resolved by consensus or referral to a third review author, but this was not necessary.

\section{Data extraction and management}

Two review authors extracted data and recorded them on a standard data extraction form. One review author entered data suitable for pooling into Review Manager 5.3 (RevMan 2014).

\section{Assessment of risk of bias in included studies}

We used the Oxford Quality Score as the basis for study inclusion, limiting inclusion to studies that were randomised and doubleblind as a minimum (Jadad 1996b).

We also completed a 'Risk of bias' table using methods adapted from those described by the Cochrane Pregnancy and Childbirth Group. Two authors independently assessed risk of bias for each study using the criteria outlined in the Cochrane Handbook for Systematic Reviews of Interventions, resolving any disagreements by discussion (Higgins 2011). We assessed the following for each study.

1. Random sequence generation (checking for possible selection bias). We assessed the method used to generate the allocation sequence as: low risk of bias (any truly random process: random number table; computer random number generator); unclear risk of bias (method used to generate sequence not clearly stated). We excluded studies using a non-random process, which were therefore at high risk of bias (odd or even date of birth; hospital or clinic record number).

2. Allocation concealment (checking for possible selection bias). The method used to conceal allocation to interventions before assignment determines whether the intervention allocation could have been foreseen in advance of, or during recruitment, or changed after assignment. We assessed the methods as: low risk of bias (telephone or central randomisation; consecutively numbered sealed opaque envelopes); unclear risk of bias (method not clearly stated). We excluded studies that did not conceal allocation, which were therefore at high risk of bias (open list).

3. Blinding of outcome assessment (checking for possible detection bias). We assessed the methods used to blind study participants and outcome assessors from knowledge of which intervention a participant received. We assessed the methods as: low risk of bias (study stated that it was blinded and 
described the method used to achieve blinding: identical tablets; matched in appearance and smell); unclear risk of bias (study stated that it was blinded but did not provide an adequate description of how blinding was achieved). We excluded studies that were not double-blind and therefore at high risk of bias.

4. Size (checking for possible biases confounded by small size). Small studies have been shown to overestimate treatment effects, probably because the conduct of small studies is more likely to be less rigorous, allowing critical criteria to be compromised (Dechartres 2013; Nüesch 2010). Studies were considered to be at low risk of bias if they had 200 participants or more, at unclear risk if they had 50 to 200 participants, and at high risk if they had fewer than 50 participants.

\section{Measures of treatment effect}

We used risk ratio (or relative risk, RR) to establish statistical difference, and numbers needed to treat to benefit (NNT) and pooled percentages as absolute measures of benefit or harm.

We use the following terms to describe adverse outcomes in terms of harm or prevention of harm.

- When significantly fewer adverse outcomes occurred with treatment than with control (placebo or active) we used the term the number needed to treat to prevent one event (NNTp).

- When significantly more adverse outcomes occurred with treatment compared with control (placebo or active) we used the term the number needed to harm or cause one event (NNH).

\section{Unit of analysis issues}

We accepted only randomisation of the individual patient.

\section{Dealing with missing data}

The only likely issue with missing data in these studies was from imputation using last observation carried forward when a patient requests rescue medication. We have previously shown that this does not affect results for up to six hours after taking study medication (Moore 2005).

\section{Assessment of heterogeneity}

We examined heterogeneity using L'Abbé plots (L'Abbé 1987), a visual method for assessing differences in results of individual studies.

\section{Assessment of reporting biases}

We assessed the number of trials of average size amongst the included studies, with a RR of one (no effect), that would be needed to reduce any statistically significant result to one that fails to meet statistical significance (following Moore 2008).

\section{Data synthesis}

For efficacy analyses we used the number of participants in each treatment group who were randomised, received medication, and provided at least one post-baseline assessment. For safety analyses we used the number of participants randomised to each treatment group who took the study medication. Results for different doses were analysed separately.

For each study we converted the mean total pain relief (TOTPAR), summed pain intensity difference (SPID), VAS TOTPAR, or VAS
SPID (see Appendix 4) values for the active and placebo groups to \%maxTOTPAR or \%maxSPID by division into the calculated maximum value (Cooper 1991). We then calculated the proportion of participants in each treatment group who achieved at least 50\%maxTOTPAR using verified equations (Moore 1996; Moore 1997a; Moore 1997b). We converted these proportions into the number of participants achieving at least 50\%maxTOTPAR by multiplying by the total number of participants in the treatment group. We used this information on the number of participants with at least 50\%maxTOTPAR for active and placebo groups to calculate RR and NNT.

We accepted the following pain measures for the calculation of TOTPAR or SPID (in order of priority: see Appendix 4).

- Five-point categorical pain relief (PR) scales with comparable wording to 'none, slight, moderate, good or complete'.

- Four-point categorical pain intensity (PI) scales with comparable wording to 'none, mild, moderate, severe'.

- VAS for pain relief.

- VAS for pain intensity.

If none of these measures were available, we used the number of participants reporting 'very good or excellent' on a five-point categorical global scale with the wording 'poor, fair, good, very good, excellent' for the number of participants achieving at least $50 \%$ pain relief (Collins 2001).

For each treatment group we extracted the number of participants reporting treatment-emergent adverse effects, and calculated relative benefit and risk estimates with 95\% confidence intervals (Cls) using a fixed-effect model (Morris 1995). We calculated NNT and $\mathrm{NNH}$ with $95 \% \mathrm{Cls}$ using the pooled number of events and the method of Cook and Sackett (Cook 1995). We assumed a statistically significant difference from control when the $95 \% \mathrm{Cl}$ of the RR did not include the number one.

\section{Subgroup analysis and investigation of heterogeneity}

We planned subgroup analyses to determine the effect of dose of ibuprofen, formulation, and presenting condition (pain model: dental versus other postoperative pain (Barden 2004)).

Ibuprofen is available as a standard (acid) formulation, and a number of fast-acting formulations. Fast-acting formulations not only produce more rapid pain relief, but better overall results, and a longer duration of action (Moore 2014; Moore 2015). For this reason, subgroup analysis is planned according to formulation of ibuprofen.

There are also issues around the dose of caffeine; if there were sufficient data we planned to analyse according to low ( $\leq 65 \mathrm{mg}$ ), medium (70 mg to $150 \mathrm{mg}$ ) and high ( $\geq 160 \mathrm{mg}$ ) doses of caffeine, but only single studies used doses other than $100 \mathrm{mg}$ caffeine (50 $\mathrm{mg}$ and $200 \mathrm{mg}$ ).

A minimum of two studies and 200 participants had to be available in any subgroup analysis (Moore 1998), which was restricted to the primary outcome (50\% pain relief over four to six hours) and the dose with the greatest amount of data. We would have determined significant differences between NNT, NNTp, or NNH for different groups in subgroup and sensitivity analyses using the $z$ test (Tramèr 1997), but this was not appropriate. 


\section{Sensitivity analysis}

No sensitivity analyses were planned.

\section{RES U L T S}

\section{Description of studies}

\section{Results of the search}

We identified five studies with 1501 participants fulfilling the inclusion criteria (Forbes 1991; Jain 1988; McQuay 1996; Sunshine
1996; NCT01929031). Four published studies (940 participants) were identified from the Cochrane review of caffeine as an analgesic adjuvant (Derry 2014) and current electronic searches (Forbes 1991; Jain 1988; McQuay 1996; Sunshine 1996). Details of individual studies are in the Characteristics of included studies table. One study (561 participants estimated) was scheduled to complete in March 2014 but remains unpublished and with no results posted on line (NCT01929031). Details are in the Characteristics of studies awaiting classification table.

See Figure 1 (Liberati 2009).

Figure 1. Flow diagram.

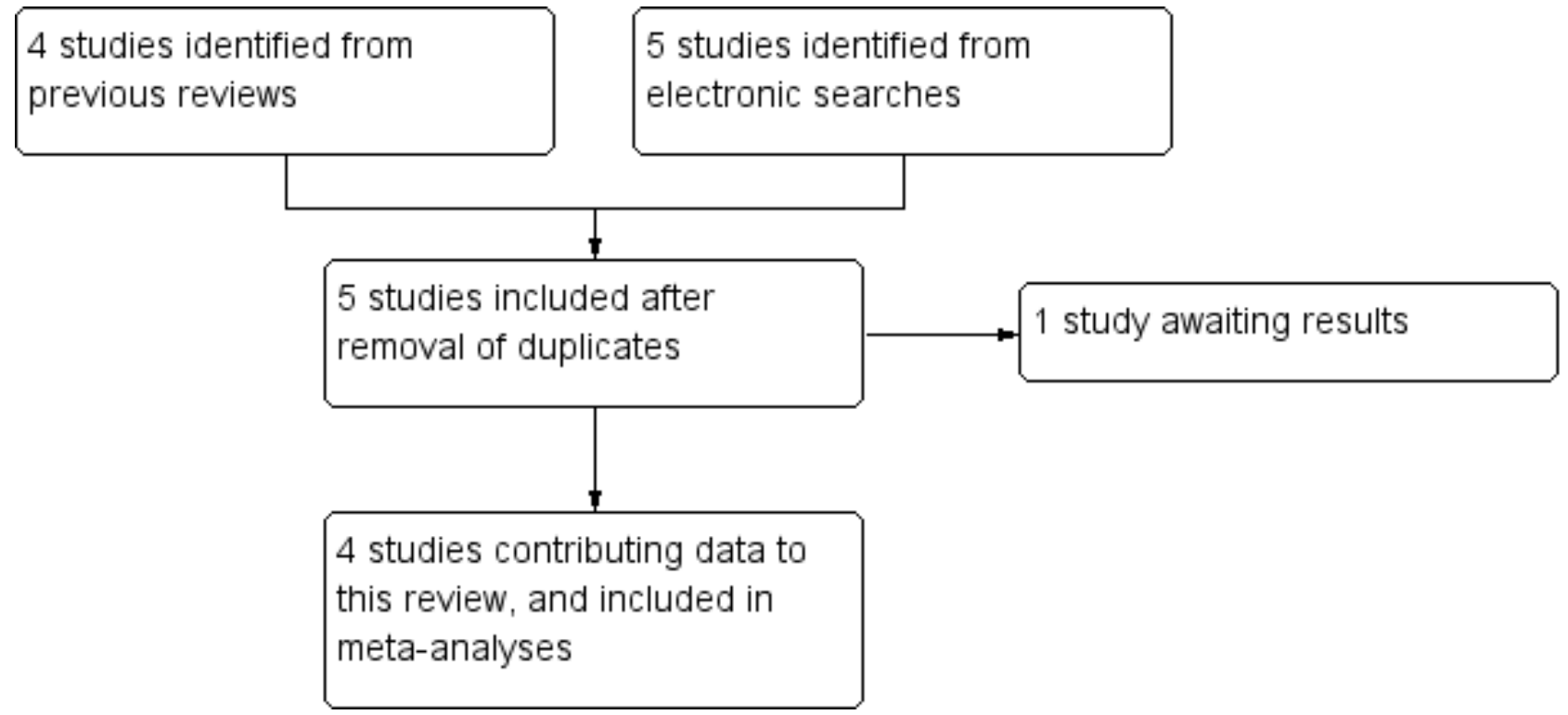

\section{Included studies}

We collected information on participant characteristics. Two of the included studies recruited men and women with pain following dental surgery (Forbes 1991; McQuay 1996), and two recruited women following episiotomy (Jain 1988; Sunshine 1996). The mean age in the studies was 25 years or less. Participants were required to be in good general health, and were excluded if they had a history of gastrointestinal disturbance, renal or hepatic disease, psychiatric disorder, or required medication that might interfere with the study results. In all studies participants took their medication when baseline pain reached moderate or severe intensity. Pain intensity and pain relief were measured at set time intervals after dosing on standard four- and five-point scales respectively, or $100 \mathrm{~mm}$ VAS.

All four of the included studies used placebo, and ibuprofen as an active comparator. A number of different treatments were administered.

- Ibuprofen $100 \mathrm{mg}+$ caffeine $100 \mathrm{mg}, \mathrm{n}=99$ (two studies).

- Ibuprofen $200 \mathrm{mg}+$ caffeine $100 \mathrm{mg}, \mathrm{n}=174$ (four studies).

- Ibuprofen $200 \mathrm{mg}+$ caffeine $50 \mathrm{mg}, \mathrm{n}=30$ (one study).

- Ibuprofen $200 \mathrm{mg}+$ caffeine $200 \mathrm{mg}, \mathrm{n}=29$ (one study).

- Ibuprofen at $50 \mathrm{mg}$ to $400 \mathrm{mg}, \mathrm{n}=448$ (four studies).
- Placebo, $\mathrm{n}=160$ (four studies).

None of the studies specified the formulation of ibuprofen used, but none indicated that a fast-acting formulation was being used.

\section{Excluded studies}

Excluded studies had been identified in other reviews (Derry 2009; Derry 2014), but the excluded studies in those reviews were checked to ensure that none might have included useful information for this review.

\section{Risk of bias in included studies}

All included studies were randomised and double-blind; one study scored 5/5 on the Oxford Quality Scale (McQuay 1996), and the remaining three scored $4 / 5$ or $3 / 5$ due to failure to report the method used to generate the randomisation schedule or blinding. It is likely that this was a failure of reporting rather than a flaw in the methods.

We assessed the risk of bias using the 'Risk of bias' tool (Figure 2). Details for each study are in the Characteristics of included studies table. 
Figure 2. Risk of bias graph: review authors' judgements about each risk of bias item presented as percentages across all included studies.

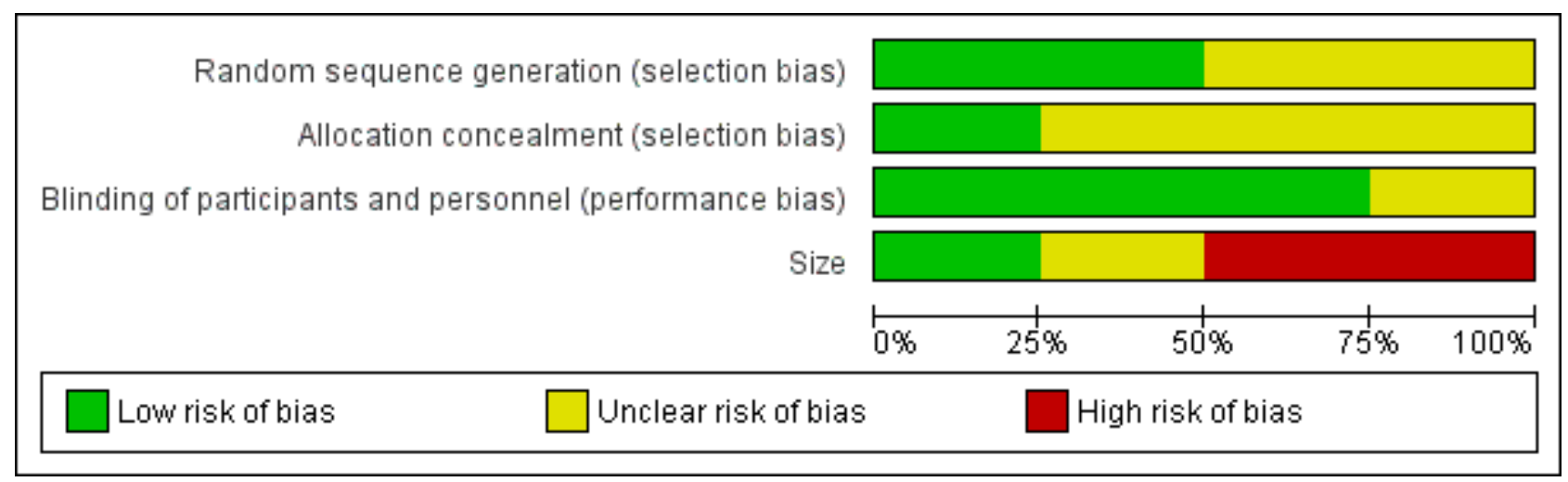

\section{Allocation}

All studies reported that they were randomised, but only one properly described the method used to generate the schedule and described the method used to conceal the random allocation (McQuay 1996), while in the other studies this was not described.

\section{Blinding}

All studies were double-blind and three adequately described how this was achieved (Forbes 1991; McQuay 1996; Sunshine 1996).

\section{Other potential sources of bias}

Treatment group size was an issue. None of the treatment groups in this review were large enough to be confident that bias would be avoided; studies had treatment group sizes that put them at high risk of bias, or with participant numbers in treatment arms that were on the borderline between high and unclear risk of bias.

\section{Effects of interventions}

See: Summary of findings for the main comparison

The small numbers of participants in most of these treatment groups meant that analysis was limited to the combinations of ibuprofen $200 \mathrm{mg}+$ caffeine $100 \mathrm{mg}$ and ibuprofen $100 \mathrm{mg}$ + caffeine
$100 \mathrm{mg}$. Comparisons of ibuprofen + caffeine with the same dose of ibuprofen alone have been done in a separate review on the effects of caffeine as an analgesic adjuvant (Derry 2014). Results for individual studies are provided in Appendix 5 (analgesia and use of rescue medication) and Appendix 6 (adverse events and withdrawals).

\section{Participants with at least $50 \%$ pain relief}

\section{Ibuprofen 200 mg + caffeine 100 mg versus placebo}

Four studies (334 participants) included comparisons of ibuprofen 200 mg + caffeine 100 mg (Forbes 1991; Jain 1988; McQuay 1996; Sunshine 1996).

- The proportion of participants with at least $50 \%$ pain relief with ibuprofen $200 \mathrm{mg}+$ caffeine $100 \mathrm{mg}$ was 59\% (103/174, range $47 \%$ to $72 \%)$.

- The proportion of participants with at least $50 \%$ pain relief with placebo was $10 \%$ (16/160, range $0 \%$ to $33 \%)$.

- The relative benefit of treatment compared with placebo was 5.5 ( $95 \% \mathrm{Cl} 3.5$ to 8.7); the NNT for one additional patient to benefit compared with placebo was 2.1 (1.8 to 2.5) (Analysis 1.1; Figure 3). Figure 4 shows the scatter plot for the individual studies.

Figure 3. Forest plot of comparison 1: Ibuprofen $200 \mathrm{mg}+$ caffeine $100 \mathrm{mg}$ versus placebo, outcome: 1.1 At least $50 \%$ maximum pain relief.

\begin{tabular}{|c|c|c|c|c|c|c|c|c|c|c|}
\hline \multirow[b]{2}{*}{ Study or Subgroup } & \multicolumn{2}{|c|}{ Experimental } & \multicolumn{2}{|c|}{ Control } & \multirow[b]{2}{*}{ Weight } & \multirow{2}{*}{$\begin{array}{c}\text { Risk Ratio } \\
\text { M-H, Fixed, 95\% Cl }\end{array}$} & \multirow{2}{*}{\multicolumn{3}{|c|}{$\begin{array}{c}\text { Risk Ratio } \\
\text { M-H, Fixed, 95\% Cl }\end{array}$}} & \multirow{2}{*}{$\begin{array}{l}\text { Risk of Bias } \\
\text { A B C D }\end{array}$} \\
\hline & Events & Total & Events & Total & & & & & & \\
\hline Forbes 1991 & 24 & 44 & 0 & 51 & $2.6 \%$ & $56.62[3.54,904.85]$ & & & $\longrightarrow$ & $\oplus ? \oplus \oplus$ \\
\hline Jain 1988 & 29 & 50 & 16 & 48 & $90.6 \%$ & $1.74[1.09,2.77]$ & & & & \\
\hline McQuay 1996 & 14 & 30 & 0 & 11 & $4.0 \%$ & $11.23[0.73,173.73]$ & & & & \\
\hline Sunshine 1996 & 36 & 50 & 0 & 50 & $2.8 \%$ & $73.00[4.60,1157.56]$ & & & $\longrightarrow$ & ? ? $?$ ? \\
\hline Total $(95 \% \mathrm{Cl})$ & & 174 & & 160 & $100.0 \%$ & $5.51[3.48,8.72]$ & & & & \\
\hline Total events & 103 & & 16 & & & & & & & \\
\hline $\begin{array}{l}\text { Heterogeneity: } \mathrm{Ch}^{2}= \\
\text { Test for overall effect }\end{array}$ & $\begin{array}{l}30.00, \mathrm{df}= \\
Z=7.29(\end{array}$ & $\begin{array}{l}3(P< \\
<0.00\end{array}$ & $\begin{array}{l}0.00001) ; \\
001)\end{array}$ & $F^{2}=90$ & & & $\stackrel{5}{0.002}$ & $\begin{array}{c}0.1 \\
\text { Placebo }\end{array}$ & $10 \begin{array}{cc}10 & 500 \\
\text { Ibuprofen/caffeine }\end{array}$ & \\
\hline $\begin{array}{l}\text { Risk of bias legend } \\
\text { (A) Random sequen } \\
\text { (B) Allocation conce } \\
\text { (C) Blinding of partic } \\
\text { (D) Size }\end{array}$ & $\begin{array}{l}\text { e generat } \\
\text { ment (sel } \\
\text { ants and }\end{array}$ & $\begin{array}{l}\text { n (sel } \\
\text { ction b } \\
\text { ersonr }\end{array}$ & $\begin{array}{l}\text { ction bia } \\
\text { as) } \\
\text { el (perfor }\end{array}$ & nance & bias) & & & & & \\
\hline
\end{tabular}


Figure 4. Studies comparing ibuprofen $200 \mathrm{mg}+$ caffeine $100 \mathrm{mg}$ with placebo.

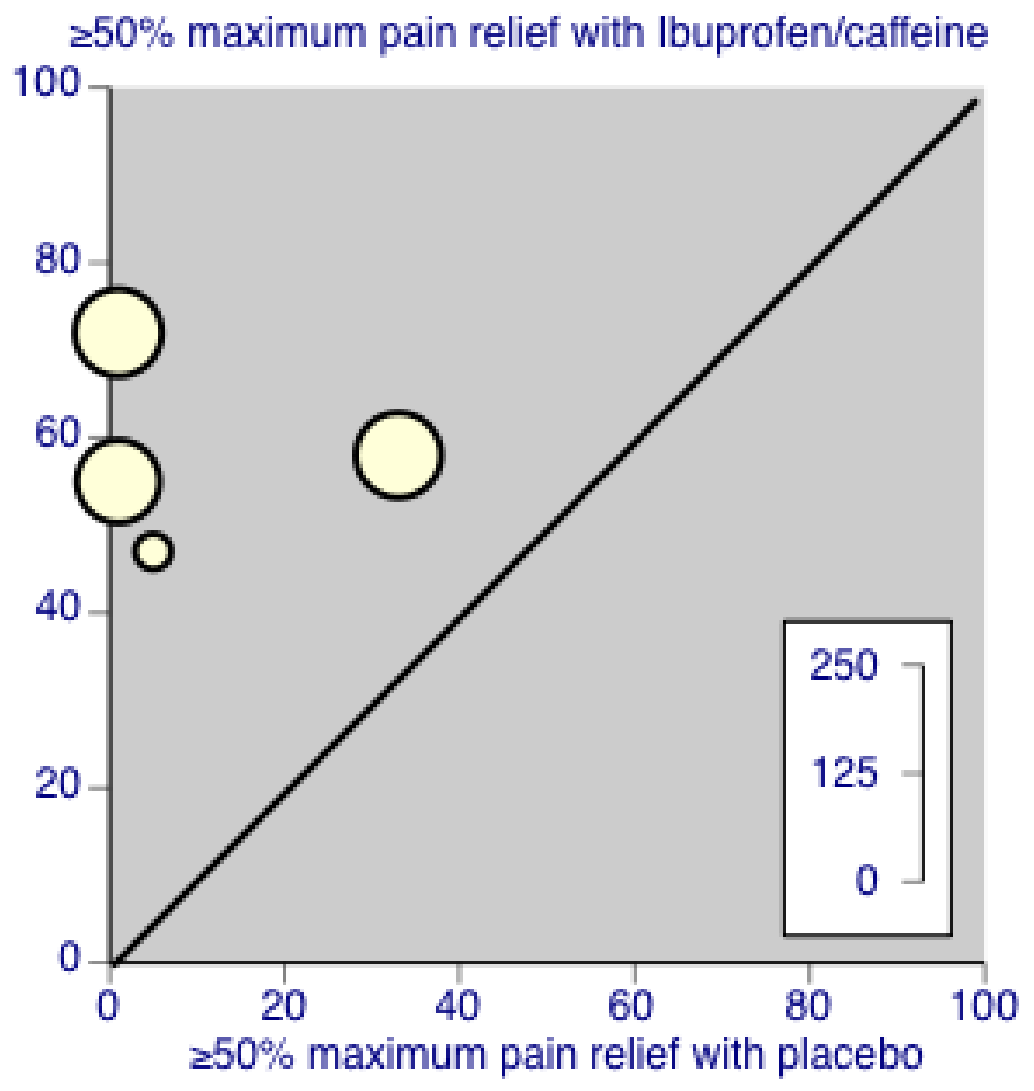

\section{Ibuprofen $100 \mathrm{mg}$ + caffeine $100 \mathrm{mg}$ versus placebo}

Two studies (200 participants) included comparisons of ibuprofen 100 mg + caffeine 100 mg (Forbes 1991; Sunshine 1996).

- The proportion of participants with at least $50 \%$ pain relief with ibuprofen $100 \mathrm{mg}$ + caffeine $100 \mathrm{mg}$ was 43\% (43/99, range 38\% to $49 \%$ ).

- The proportion of participants with at least $50 \%$ pain relief with placebo was $0 \%(0 / 101)$.

- The relative benefit of treatment compared with placebo was 45 (6.3 to 319); the NNT for one additional participant to benefit compared with placebo was 2.4 (1.9 to 3.1) (Analysis 2.1)

\section{Use of rescue medication: Median (or mean) time to use of rescue medication}

Only one study reported data for this outcome (Forbes 1991). The time to use of rescue medication was longer for all active treatments than placebo, but there were too few data for analysis.

\section{Use of rescue medication: Participants remedicating}

\section{Ibuprofen 200 mg + caffeine 100 mg versus placebo}

The number of participants remedicating was typically measured within six or eight hours.

Three studies (293 participants) included comparisons of ibuprofen 200 mg + caffeine 100 mg (Forbes 1991; Jain 1988; Sunshine 1996).
- The proportion of participants remedicating with ibuprofen 200 $\mathrm{mg}+$ caffeine $100 \mathrm{mg}$ was $26 \%$ (38/144, range $2 \%$ to $57 \%$ ).

- The proportion of participants remedicating with placebo was $60 \%$ (90/149, range $38 \%$ to $94 \%)$.

- The RR of treatment compared with placebo was 0.5 (0.4 to 0.6 ); the NNTp for one fewer participant to remedicate compared with placebo was 2.9 (2.2 to 4.3) (Analysis 1.2).

\section{Ibuprofen $100 \mathrm{mg}$ + caffeine $100 \mathrm{mg}$ versus placebo}

Two studies (200 participants) included comparisons of ibuprofen 100 mg + caffeine 100 mg (Forbes 1991; Sunshine 1996).

- The proportion of participants remedicating with ibuprofen 100 $\mathrm{mg}+$ caffeine $100 \mathrm{mg}$ was $34 \%$ (34/99, range $0 \%$ to $68 \%$ ).

- The proportion of participants remedicating with placebo was $66 \%$ (67/101, range $38 \%$ to $94 \%)$.

- The RR of treatment compared with placebo was 0.5 (0.4 to 0.7 ); the NNTp for one fewer participant to remedicate compared with placebo was 3.1 (2.2 to 5.3) (Analysis 2.2).

\section{Adverse events}

All studies reported the number of participants experiencing any adverse event. 


\section{Ibuprofen 200 mg + caffeine 100 mg versus placebo}

Four studies (336 participants) included comparisons of ibuprofen 200 mg + caffeine 100 mg (Forbes 1991; Jain 1988; McQuay 1996; Sunshine 1996).

- The proportion of participants experiencing an adverse event with ibuprofen $200 \mathrm{mg}$ + caffeine $100 \mathrm{mg}$ was $11 \%$ (19/174, range $7 \%$ to $18 \%)$.

- The proportion of participants experiencing an adverse event with placebo was $6.2 \%$ (10/162, range $0 \%$ to $15 \%)$.

- The RR of treatment compared with placebo was 1.9 (0.91 to 3.8); the NNH was not calculated (Analysis 1.3).

\section{Ibuprofen $100 \mathrm{mg}$ + caffeine $100 \mathrm{mg}$ versus placebo}

Two studies (200 participants) included comparisons of ibuprofen $100 \mathrm{mg}+$ caffeine $100 \mathrm{mg}$ (Forbes 1991; Sunshine 1996).

- The proportion of participants experiencing an adverse event with ibuprofen $100 \mathrm{mg}+$ caffeine $100 \mathrm{mg}$ was 14\% (14/99, range $4 \%$ to $24 \%)$.

- The proportion of participants experiencing an adverse event with placebo was $8 \%$ ( $8 / 101$, range $0 \%$ to $15 \%)$.

- The RR of treatment compared with placebo was 1.8 (0.8 to 3.9); the NNH was not calculated (Analysis 2.3).

\section{Serious adverse events}

No study reported that there were serious adverse events, and three specifically reported that no serious adverse events occurred.

\section{Withdrawals}

Withdrawals due to lack of efficacy have been considered under 'Use of rescue medication' (above) and were not consistently reported.

There were no adverse event withdrawals, or other withdrawals.

\section{DISCUSSION}

The background to this review is a knowledge that combinations of different analgesics provide additive effects in acute pain and migraine (Moore 2011b; Moore 2012). The aim was to assess the analgesic efficacy of ibuprofen and caffeine combination analgesics because caffeine is a known analgesic adjuvant for acute pain at doses of about $100 \mathrm{mg}$ (Derry 2014). Ibuprofen combined with caffeine is not commonly available except in some South American countries, but the combination is easily achieved by taking ibuprofen tablets with caffeine tablets, a reasonably strong cup of coffee, or perhaps some other caffeine-containing drinks.

\section{Summary of main results}

Ibuprofen plus caffeine was effective when taken in combination as a single oral dose for treatment of established moderate or severe postoperative pain. NNT values for ibuprofen $200 \mathrm{mg}+$ caffeine 100 $\mathrm{mg}$ of 2.1 (1.8 to 2.5) and for ibuprofen $100 \mathrm{mg}+$ caffeine $100 \mathrm{mg}$ of 2.4 (1.9 to 3.1) are amongst the lowest (best) values for analgesics in this pain model (Moore 2011a). These results for the proportion of participants achieving at least $50 \%$ of maximum pain relief were supported by similar low NNT values for remedication.
Moreover, these measured NNT values are close to the values predicted by a model for acute pain combinations (Moore 2012). It predicts that the absolute benefit increase for a combination will be the sum of the benefit increases of two different drugs. Using absolute benefit increases for appropriate doses of ibuprofen and caffeine from Cochrane reviews produces predicted NNT values in the range of 2.0 to 2.2 for ibuprofen $200 \mathrm{mg}+$ caffeine $100 \mathrm{mg}$ and 3.0 to 3.2 for ibuprofen $100 \mathrm{mg}+$ caffeine $100 \mathrm{mg}$. The prediction is very accurate for ibuprofen $200 \mathrm{mg}+$ caffeine $100 \mathrm{mg}$ where there was most information, but somewhat less so for ibuprofen $100 \mathrm{mg}+$ caffeine $100 \mathrm{mg}$ where there was limited information for the combination here, and for ibuprofen $100 \mathrm{mg}$ alone (Derry 2009).

As best we know, all four contributing studies used a standard ibuprofen acid formulation. Standard acid formulation ibuprofen has an NNT of 2.9 for $200 \mathrm{mg}$ and 2.5 for $400 \mathrm{mg}$. Fast-acting formulations have NNTs of 2.1 for $200 \mathrm{mg}$ and $400 \mathrm{mg}$ (Moore 2014). The result for a standard acid formulation of ibuprofen combined with caffeine is therefore not unimportant, as it produces a more effective analgesic response from a less effective formulation. Moreover, it is at least possible that this can be accomplished by a low technology and low cost intervention, namely a caffeinated drink. Whether adding caffeine to a fast-acting formulation would achieve similar additional benefit is not known.

\section{Overall completeness and applicability of evidence}

The main limitation of the review was the small number of studies and participants. However, the general results are in accord with those known for ibuprofen in combination with codeine and paracetamol (Derry 2013a; Derry 2013b), for caffeine as an analgesic adjuvant (Derry 2014), and for combination drugs in acute pain (Moore 2011b; Moore 2012). The additional effect of caffeine (here with ibuprofen) is about the same magnitude as that found when doubling the dose of the analgesic (Derry 2014; Moore 2012).

The limited number of studies and participants did not allow for any sensible assessment of common or rare adverse events, although both ibuprofen and caffeine are widely studied.

\section{Quality of the evidence}

The studies themselves were of high quality but sample sizes were somewhat limited. Older studies in postpartum and dental pain tended historically to be small and meta-analyses of small trials are susceptible to overestimation of effects (Dechartres 2013; Nüesch 2010). The small study size explains the high $I^{2}$ values for some heterogeneity tests, though the spread of data was consistent between studies (Figure 4).

\section{Potential biases in the review process}

We carried out extensive searches to identify relevant studies but there always remains the possibility of unidentified studies. We calculated that for ibuprofen $200 \mathrm{mg}+$ caffeine $100 \mathrm{mg}$, an additional 938 participants would have to have been involved in unpublished trials with zero treatment effects for the NNT for at least $50 \%$ pain relief to increase above 8 , a level we consider to be the limit of clinical utility for this outcome (Moore 2008).

A large number of clinical trials relating to caffeine as an analgesic adjunct for acute pain have only been published in part, or in reviews, or without full publication or clinical trial reports made available. In one review, only four of 30 studies had previously 
been published, and no additional information on unpublished studies was available in that review (Laska 1984). However, there is considerable evidence that a positive effect of caffeine occurs in these studies (Laska 1984; Sawynok 1993). In this circumstance it is unlikely that publication bias would play any role in changing either the direction or magnitude of the result.

\section{Agreements and disagreements with other studies or reviews}

A review of ibuprofen + caffeine in postsurgical pain did not calculate the beneficial effect of combinations compared with placebo (Li Wan Po 1998). A previous review had indicated that the addition of caffeine to analgesic drugs for acute pain produced a significant increase in the number of people achieving good levels of pain relief (Derry 2014). We know of no previous reviews with the analyses reported here.

\section{AUTHORS' CONCLUSIONS}

\section{Implications for practice}

\section{For people with moderate-to-severe acute pain}

A single tablet of ibuprofen $200 \mathrm{mg}$ taken with a dose of up to 100 $\mathrm{mg}$ of caffeine produces a strong analgesic effect. Better pain relief can come at a lower dose of drug. In the absence of medicines with a fixed dose combination of ibuprofen + caffeine, a single tablet of ibuprofen $200 \mathrm{mg}$ taken with a strong cup of coffee or a caffeinated drink containing about $100 \mathrm{mg}$ of caffeine produces analgesia as good as or better than taking two tablets of ibuprofen $200 \mathrm{mg}$ without the coffee or drink.

\section{For clinicians}

Especially for people who have frequent acute pain, or where it may be important to limit exposure to NSAIDs, the use of a lower dose of ibuprofen together with a source of caffeine amounting to $100 \mathrm{mg}$ can produce very good levels of pain relief.

\section{For policy-makers}

Population exposure to NSAIDs is a potential public health risk. Risks are largely dose related, and advice about the concomitant use of low dose ibuprofen together with caffeine potentially reduces population exposure and risk.

\section{For funders}

This is potentially a low cost way of achieving good pain relief Ideally, fixed dose formulations would achieve that, but in their absence there are alternative ways to deliver good pain relief at low cost.

\section{Implications for research}

\section{General}

Very considerable research has been done on analgesic effects of ibuprofen in single dose analgesic trials to test its analgesic efficacy.
Often it is used as a standard analgesic at the $400 \mathrm{mg}$ dose. This may be why the current total of participants in comparisons of ibuprofen $400 \mathrm{mg}$ with placebo amounts to some 6000 , with another 2000 in comparisons of ibuprofen $200 \mathrm{mg}$ with placebo. By contrast, only 334 participants contributed to the main analysis of ibuprofen 200 $\mathrm{mg}+$ caffeine $100 \mathrm{mg}$ and placebo.

This is barely adequate to measure the NNT accurately, and quite inadequate for any assessment of adverse events.

Given the very good pain relieving effects of the combination, and the potential to minimise population exposure to NSAIDs (as with fast-acting ibuprofen formulations), as well as to minimise exposure to NSAID and opioid combinations, research on this combination of ibuprofen plus caffeine in acute pain should have a higher priority.

Generalisability could be confirmed by including older participants in future studies, although we know of no reason why age should influence the result.

\section{Design}

The current design of acute pain studies is well understood, and has proven to be robust.

\section{Measurement (endpoints)}

Endpoints in these studies have been extensively validated, as have standard pain scoring systems. The main outcome used is one valued by patients with pain, and has economic benefits in most circumstances.

\section{Comparison between active treatments}

The standardised nature of the study design means that indirect comparisons with placebo are valid, as evidenced by independent research on the topic. There is, however, a very large body of information amenable to network meta-analysis. While unlikely to provide much in the way of new insights, it could prove an invaluable tool for testing network meta-analytical methods.

\section{ACKNOWLEDGEMENTS}

This review received infrastructure support from the Oxford Pain Relief Trust.

Funding Acknowledgement: The National Institute for Health Research (NIHR) is the largest single funder of the Cochrane Pain, Palliative and Supportive Care Review Group. Disclaimer: The views and opinions expressed therein are those of the authors and do not necessarily reflect those of the NIHR, National Health Service, or the Department of Health. 


\section{R E F E R E N C E S}

\section{References to studies included in this review}

Forbes 1991 \{published data only\}

Forbes JA, Beaver WT, Jones KF, Kehm CJ, Smith WK, Gongloff CM, et al. Effect of caffeine on ibuprofen analgesia in postoperative oral surgery pain. Clinical Pharmacology and Therapeutics 1991;49(6):674-84.

\section{Jain 1988 \{published data only\}}

Jain AK, McMahon FG, Ryan JR, Narcisse C. A double-blind study of ibuprofen $200 \mathrm{mg}$ in combination with caffeine 100 $\mathrm{mg}$, ibuprofen $400 \mathrm{mg}$, and placebo in episiotomy pain. Current Therapeutic Research 1988;43(4):762-9.

\section{McQuay 1996 \{published data only\}}

McQuay HJ, Angell K, Carroll D, Moore RA, Juniper RP. Ibuprofen compared with ibuprofen plus caffeine after third molar surgery. Pain 1996;66(2-3):247-51.

\section{Sunshine 1996 \{published data only\}}

Sunshine A, Zighelboim I, Bartizek RD. A double-blind, placebocontrolled, single-dose comparison study of ibuprofen, and ibuprofen in combination with caffeine, in the treatment of postepisiotomy pain. Royal Society of Medicine International Congress and Symposium Series 218 1996;218:105-88.

\section{References to studies awaiting assessment}

NCT01929031 \{unpublished data only\}

\section{Additional references}

\section{Barden 2004}

Barden J, Edwards JE, McQuay HJ, Moore RA. Pain and analgesic response after third molar extraction and other postsurgical pain. Pain 2004;107(1-2):86-90. [DOI: 10.1016/ j.pain.2003.09.021]

\section{Clarke 2012}

Clarke R, Derry S, Moore RA, McQuay HJ. Single dose oral etoricoxib for acute postoperative pain in adults. Cochrane Database of Systematic Reviews 2012, Issue 4. [DOI: 10.1002/14651858.CD004309.pub3]

\section{Collins 1997}

Collins SL, Moore RA, McQuay HJ. The visual analogue pain intensity scale: what is moderate pain in millimetres?. Pain 1997;72:95-7. [DOI: 10.1016/S0304-3959(97)00005-5]

\section{Collins 2001}

Collins SL, Edwards J, Moore RA, Smith LA, McQuay HJ. Seeking a simple measure of analgesia for mega-trials: is a single global assessment good enough?. Pain 2001;91(1-2):189-94. [DOI: 10.1016/S0304-3959(00)00435-8]

\section{Cook 1995}

Cook RJ, Sackett DL. The number needed to treat: a clinically useful measure of treatment effect. BMJ 1995;310:452-4.

\section{Cooper 1991}

Cooper SA. Single-dose analgesic studies: the upside and downside of assay sensitivity. In: Max MB, Portenoy RK, Laska EM editor(s). The Design of Analgesic Clinical Trials. Advances in Pain Research and Therapy. Vol. 18, New York: Raven Press, 1991:117-24.

\section{Craig 2012}

Craig DG, Bates CM, Davidson JS, Martin KG, Hayes PC, Simpson KJ. Staggered overdose pattern and delay to hospital presentation are associated with adverse outcomes following paracetamol-induced hepatotoxicity. British Journal of Clinical Pharmacology 2012;73(2):285-94. [DOI: 10.1111/ j.1365-2125.2011.04067.x]

\section{Dechartres 2013}

Dechartres A, Trinquart L, Boutron I, Ravaud P. Influence of trial sample size on treatment effect estimates: metaepidemiological study. BMJ 2013;346:f2304. [DOI: 10.1136/ bmj.f2304]

\section{Derry 2009}

Derry C, Derry S, Moore RA, McQuay HJ. Single dose oral ibuprofen for acute postoperative pain in adults. Cochrane Database of Systematic Reviews 2009, Issue 3. [DOI: 10.1002/14651858.CD001548.pub2]

\section{Derry 2010}

Derry S, Moore RA, McQuay HJ. Single dose oral codeine, as a single agent, for acute postoperative pain in adults. Cochrane Database of Systematic Reviews 2010, Issue 4. [DOI: 10.1002/14651858.CD008099.pub2]

\section{Derry 2013a}

Derry CJ, Derry S, Moore RA. Single dose oral ibuprofen plus paracetamol (acetaminophen) for acute postoperative pain. Cochrane Database of Systematic Reviews 2013, Issue 6. [DOI: 10.1002/14651858.CD010210.pub2]

\section{Derry 2013b}

Derry S, Karlin SM, Moore RA. Single dose oral ibuprofen plus codeine for acute postoperative pain in adults. Cochrane Database of Systematic Reviews 2013, Issue 3. [DOI: 10.1002/14651858.CD010107.pub2]

\section{Derry 2013c}

Derry S, Derry CJ, Moore RA. Single dose oral ibuprofen plus oxycodone for acute postoperative pain in adults. Cochrane Database of Systematic Reviews 2013, Issue 6. [DOI: 10.1002/14651858.CD010289.pub2]

\section{Derry 2014}

Derry CJ, Derry S, Moore RA. Caffeine as an analgesic adjuvant for acute pain in adults. Cochrane 
Database of Systematic Reviews 2014, Issue 12. [DOI: 10.1002/14651858.CD009281.pub3]

\section{Diamond 2000}

Diamond S, Balm TK, Freitag FG. Ibuprofen plus caffeine in the treatment of tension-type headache. Clinical Pharmacology and Therapeutics 2000;68(3):312-9. [DOI: 10.1067/mcp.2000.109353]

\section{Donovan 2001}

Donovan JL, DeVane CL. A primer on caffeine pharmacology and its drug interactions in clinical psychopharmacology. Psychopharmacology Bulletin 2001;35(3):30-48.

\section{FitzGerald 2001}

FitzGerald GA, Patrono C. The coxibs, selective inhibitors of cyclooxygenase-2. New England Journal of Medicine 2001;345(6):433-42. [DOI: 10.1056/NEJM200108093450607]

\section{Forrest 2002}

Forrest JB, Camu F, Greer IA, Kehlet H, Abdalla M, Bonnet F. Ketorolac, diclofenac, and ketoprofen are equally safe for pain relief after major surgery. British Journal of Anaesthesia 2002;88(2):227-33. [DOI: 10.1093/bja/88.2.227]

\section{Hernandez-Diaz 2001}

Hernández-Díaz S, García-Rodríguez LA. Epidemiologic assessment of the safety of conventional nonsteroidal anti-inflammatory drugs. The American Journal of Medicine 2001;110(Suppl 3A):20S-7S. [DOI: 10.1016/ S0002-9343(00)00682-3]

\section{Higgins 2011}

Higgins JPT, Altman DG, Sterne JAC (editors). Chapter 8: Assessing risk of bias in included studies. In: Higgins JPT, Green S (editors). Cochrane Handbook for Systematic Reviews of Interventions. Version 5.1.0 [updated March 2011]. The Cochrane Collaboration, 2011. Available from www.cochranehandbook.org.

\section{ledema 2011}

ledema J. Caution with codeine. Australian Prescriber 2011;34:133-5

\section{Jadad 1996a}

Jadad AR, Carroll D, Moore A, McQuay H. Developing a database of published reports of randomised clinical trials in pain research. Pain 1996;66:239-46. [DOI: 10.1016/0304-3959(96)03033-3]

\section{Jadad 1996b}

Jadad AR, Moore RA, Carroll D, Jenkinson C, Reynolds DJM, Gavaghan DJ, et al. Assessing the quality of reports of randomized clinical trials: is blinding necessary?. Controlled Clinical Trials 1996;17:1-12. [DOI: 10.1016/0197-2456(95)00134-4]

\section{L'Abbé 1987}

L'Abbé KA, Detsky AS, O'Rourke K. Meta-analysis in clinical research. Annals of Internal Medicine 1987;107:224-33.

\section{Laska 1984}

Laska EM, Sunshine A, Mueller F, Elvers WB, Siegel C, Rubin A. Caffeine as an analgesic adjuvant. JAMA 1984;251(13):1711-8.

\section{Li Wan Po 1998}

Li Wan Po A, Zhang WY. Analgesic efficacy of ibuprofen alone and in combination with codeine or caffeine in postsurgical pain: a meta-analysis. European Journal of Clinical Pharmacology 1998;53:303-11.

\section{Liberati 2009}

Liberati A, Altman DG, Tetzlaff J, Mulrow C, Gøtzsche PC, Ioannidis JP, et al. The PRISMA statement for reporting systematic reviews and meta-analyses of studies that evaluate healthcare interventions: explanation and elaboration. BMJ 2009;339:b2700. [DOI: 10.1136/bmj.b2700]

\section{Lopez 2006}

López JR, Domínguez-Ramírez AM, Cook HJ, Bravo G, Díaz-Reval MI, Déciga-Campos M, et al. Enhancement of antinociception by co-administration of ibuprofen and caffeine in arthritic rats. European Journal of Pharmacology 2006;544(1-3):31-8. [DOI: 10.1016/j.ejphar.2006.06.041]

\section{McQuay 2005}

McQuay HJ, Moore RA. Placebo. Postgraduate Medical Journal 2005;81:155-60. [DOI: 10.1136/pgmj.2004.024737]

\section{McQuay 2012}

McQuay HJ, Derry S, Eccleston C, Wiffen PJ, Moore RA. Evidence for analgesic effect in acute pain - 50 years on. Pain 2012;153(7):1364-7. [DOI: 10.1016/j.pain.2012.01.024]

\section{Moore 1996}

Moore A, McQuay H, Gavaghan D. Deriving dichotomous outcome measures from continuous data in randomised controlled trials of analgesics. Pain 1996;66(2-3):229-37.

\section{Moore 1997a}

Moore A, McQuay H, Gavaghan D. Deriving dichotomous outcome measures from continuous data in randomised controlled trials of analgesics: verification from independent data. Pain 1997;69(1-2):127-30.

\section{Moore 1997b}

Moore A, Moore O, McQuay H, Gavaghan D. Deriving dichotomous outcome measures from continuous data in randomised controlled trials of analgesics: use of pain intensity and visual analogue scales. Pain 1997;69(3):311-5.

\section{Moore 1998}

Moore RA, Gavaghan D, Tramer MR, Collins SL, McQuay HJ. Size is everything - large amounts of information are needed to overcome random effects in estimating direction and magnitude of treatment effects. Pain 1998;78(3):209-16. [DOI: 10.1016/S0304-3959(98)00140-7]

\section{Moore 2003}

Moore RA, Edwards J, Barden J, McQuay HJ. Bandolier's Little Book of Pain. Oxford: Oxford University Press, 2003. [ISBN: 0-19-263247-7] 


\section{Moore 2005}

Moore RA, Edwards JE, McQuay HJ. Acute pain: individual patient meta-analysis shows the impact of different ways of analysing and presenting results. Pain 2005;116(3):322-31. [DOI: 10.1016/j.pain.2005.05.001]

\section{Moore 2006}

Moore A, McQuay H. Bandolier's Little Book of Making Sense of the Medical Evidence. Oxford: Oxford University Press, 2006. [ISBN: 0-19-856604-2]

\section{Moore 2008}

Moore RA, Barden J, Derry S, McQuay HJ. Managing potential publication bias. In: McQuay HJ, Kalso E, Moore RA editor(s). Systematic Reviews in Pain Research: Methodology Refined. Seattle: IASP Press, 2008:15-24. [ISBN: 978-0-931092-69-5]

\section{Moore 2011a}

Moore RA, Derry S, McQuay HJ, Wiffen PJ. Single dose oral analgesics for acute postoperative pain in adults. Cochrane Database of Systematic Reviews 2011, Issue 9. [DOI: 10.1002/14651858.CD008659.pub2]

\section{Moore 2011b}

Moore RA, Straube S, Paine J, Derry S, McQuay HJ. Minimum efficacy criteria for comparisons between treatments using individual patient meta-analysis of acute pain trials: examples of etoricoxib, paracetamol, ibuprofen, and ibuprofen/ paracetamol combinations after third molar extraction. Pain 2011;152(5):982-9. [DOI: 10.1016/j.pain.2010.11.030]

\section{Moore 2012}

Moore RA, Derry CJ, Derry S, Straube S, McQuay HJ. A conservative method of testing whether combination analgesics produce additive or synergistic effects using evidence from acute pain and migraine. European Journal of Pain 2012;16(4):585-91. [DOI: 10.1016/j.ejpain.2011.08.009]

\section{Moore 2013}

Moore RA, Straube S, Aldington D. Pain measures and cut-offs - 'no worse than mild pain' as a simple, universal outcome. Anaesthesia 2013;68(4):400-12. [DOI: 10.1111/anae.12148]

\section{Moore 2014}

Moore RA, Derry S, Straube S, Ireson-Paine J, Wiffen PJ. Faster, higher, stronger? Evidence for formulation and efficacy for ibuprofen in acute pain. Pain 2014;155(1):14-21. [DOI: 10.1016/ j.pain.2013.08.013]

\section{Moore 2015}

Moore RA, Derry S, Straube S, Ireson-Paine J, Wiffen PJ. Validating speed of onset as a key component of good analgesic response in acute pain. European Journal of Pain 2015;19(2):187-92. [DOI: 10.1002/ejp.536]

\section{Morris 1995}

Morris JA, Gardner MJ. Calculating confidence intervals for relative risk, odds ratios and standardised ratios and rates. In: Gardner MJ, Altman DG editor(s). Statistics With ConfidenceConfidence Intervals and Statistical Guidelines. London: BMJ, 1995:50-63.

\section{Nüesch 2010}

Nüesch E, Trelle S, Reichenbach S, Rutjes AW, Tschannen B, Altman DG, et al. Small study effects in meta-analyses of osteoarthritis trials: meta-epidemiological study. BMJ 2010;341:c3515. [DOI: 10.1136/bmj.c3515]

\section{Rapoport 1999}

Rapoport RJ. The safety of NSAIDs and related drugs for the management of acute pain: maximizing benefits and minimizing risks. Cancer Control 1999;6(2 Suppl 1):18-21.

\section{Renner 2007}

Renner B, Clarke G, Grattan T, Beisel A, Mueller C, Werner U, et al. Caffeine accelerates absorption and enhances the analgesic effect of acetaminophen. Journal of Clinical Pharmacology 2007;47(6):715-26.

\section{RevMan 2014 [Computer program]}

The Nordic Cochrane Centre, The Cochrane Collaboration. Review Manager (RevMan). Version 5.3. Copenhagen: The Nordic Cochrane Centre, The Cochrane Collaboration, 2014.

\section{Sawynok 1993}

Sawynok J, Yaksh TL. Caffeine as an analgesic adjuvant: a review of pharmacology and mechanisms of action. Pharmacological Reviews 1993;45(1):43-85.

\section{Sawynok 2011a}

Sawynok J. Methylxanthines and pain. Handbook of Experimental Pharmacology 2011;200:311-29. [DOI: 10.1007/978-3-642-13443-2_11]

\section{Sawynok 2011b}

Sawynok J. Caffeine and pain. Pain 2011;152(4):726-9. [DOI: 10.1016/j.pain.2010.10.011]

\section{Toms 2008}

Toms L, McQuay HJ, Derry S, Moore RA. Single dose oral paracetamol (acetaminophen) for postoperative pain in adults. Cochrane Database of Systematic Reviews 2008, Issue 4. [DOI: 10.1002/14651858.CD004602.pub2]

\section{Tramèr 1997}

Tramèr MR, Reynolds DJM, Moore RA, McQuay HJ. Impact of covert duplicate results on meta-analysis: a case study. BMJ 1997;315:635-9. [DOI: 10.1136/bmj.315.7109.635]

\section{Zhang 2001}

Zhang WY. A benefit-risk assessment of caffeine as an analgesic adjuvant. Drug Safety 2001;24(15):1127-42. 
CHARACTERISTICS OF STUDIES

Characteristics of included studies [ordered by study ID]

Forbes 1991

Methods Multicentre, randomised, double-blind, placebo-controlled, parallel group study, with a single oral dose administered at the onset of moderate or severe pain

Eight-hour study period, with assessments at baseline, 0.5, one, two, three, four, five, six, seven, and eight hours post-dose

Pental surgery - third molar removal
Caffeine-containing foods and beverages were prohibited for four hours before taking study medica-
tion and for the following 8-hour study period
Patients were at least 15 years of age
N $=362$ (298 for efficacy)
M: $121, \mathrm{~F}: 177$
Mean age: 22 years

\begin{tabular}{|c|c|}
\hline \multirow[t]{6}{*}{ Interventions } & Ibuprofen $100 \mathrm{mg}+$ caffeine $100 \mathrm{mg}, \mathrm{n}=49$ for efficacy \\
\hline & Ibuprofen $100 \mathrm{mg}, \mathrm{n}=49$ for efficacy \\
\hline & Ibuprofen $200 \mathrm{mg}+$ caffeine $100 \mathrm{mg}, \mathrm{n}=44$ for efficacy \\
\hline & Ibuprofen $200 \mathrm{mg}, \mathrm{n}=48$ for efficacy \\
\hline & Ibuprofen $50 \mathrm{mg}, \mathrm{n}=57$ for efficacy \\
\hline & Placebo, $n=51$ for efficacy \\
\hline
\end{tabular}

\begin{tabular}{ll}
\hline Outcomes & PI: standard 4-point scale \\
PR: standard 5-point scale \\
PGE: standard 5-point scale \\
Withdrawals and dropouts \\
Serious adverse events \\
\hline Notes & Oxford Quality Score: R1, DB2, W1. Total =4 \\
\hline
\end{tabular}

Risk of bias

\begin{tabular}{lll}
\hline Bias & Authors' judgement & Support for judgement \\
\hline $\begin{array}{l}\text { Random sequence genera- } \\
\text { tion (selection bias) }\end{array}$ & Low risk & Gives reference to methods in earlier reports that are low risk \\
\hline $\begin{array}{l}\text { Allocation concealment } \\
\text { (selection bias) }\end{array}$ & Unclear risk & Not reported \\
\hline $\begin{array}{l}\text { Blinding of participants } \\
\begin{array}{l}\text { and personnel (perfor- } \\
\text { mance bias) }\end{array}\end{array}$ & Low risk \\
All outcomes & \\
\hline
\end{tabular}


Forbes 1991 (Continued)
Size
Low risk
$<50$ participants in relevant treatment groups

Jain 1988

\begin{tabular}{|c|c|}
\hline Methods & $\begin{array}{l}\text { Single-centre, randomised, double-blind, placebo-controlled, parallel group study, with a single oral } \\
\text { dose administered after the onset of moderate or severe pain } \\
\text { Six-hour study period, with assessments at baseline, } 0.5 \text {, one, two, three, four, five, and six hours post- } \\
\text { dose }\end{array}$ \\
\hline Participants & $\begin{array}{l}\text { Women with moderate or severe pain following episiotomy } \\
\mathrm{N}=150 \text { ( } 147 \text { for efficacy) } \\
\text { Mean age } 23 \text { years }\end{array}$ \\
\hline Interventions & $\begin{array}{l}\text { Ibuprofen } 200 \mathrm{mg}+\text { caffeine } 100 \mathrm{mg}, \mathrm{n}=50 \\
\text { Ibuprofen } 400 \mathrm{mg}, \mathrm{n}=49 \\
\text { Placebo, } \mathrm{n}=48\end{array}$ \\
\hline Outcomes & $\begin{array}{l}\text { PI: standard 4-point scale } \\
\text { PR: 5-point scale marked with } 0 \text { to } 100 \% \text { relief at different points 0-4 } \\
\text { Time of meaningful relief } \\
\text { PGE: standard 5-point scale } \\
\text { Withdrawals and dropouts } \\
\text { Serious adverse events }\end{array}$ \\
\hline Notes & Oxford Quality Score: R1, DB1, W1. Total = 3 \\
\hline
\end{tabular}

\section{Risk of bias}

\begin{tabular}{lll}
\hline Bias & Authors' judgement & Support for judgement \\
\hline $\begin{array}{l}\text { Random sequence genera- } \\
\text { tion (selection bias) }\end{array}$ & Unclear risk & No details of randomisation method given \\
\hline $\begin{array}{l}\text { Allocation concealment } \\
\text { (selection bias) }\end{array}$ & Unclear risk & No details of concealment method given \\
\hline $\begin{array}{l}\text { Blinding of participants } \\
\text { and personnel (perfor- } \\
\text { mance bias) } \\
\text { All outcomes }\end{array}$ & Unclear risk & No details of blinding method given \\
\hline Size & High risk & 49 and 50 participants in relevant treatment groups \\
\hline
\end{tabular}


McQuay 1996

Methods Single-centre, randomised, double-blind, placebo-controlled, parallel group study, with a single oral dose administered after onset of moderate or severe pain

Eight-hour study period with first two hours in hospital. Time points of individual assessments not reported

Participants
Dental surgery - third molar removal.
No caffeine-containing products from midnight on the eve
in the 12 hours before surgery
$\mathrm{N}=164$ (161 for efficacy)
M: $59, \mathrm{~F}: 102$
Mean age: 25 years
Ibuprofen $200 \mathrm{mg}+$ caffeine $50 \mathrm{mg}, \mathrm{n}=30$ for efficacy
Ibuprofen $200 \mathrm{mg}+$ caffeine $100 \mathrm{mg}, \mathrm{n}=30$ for efficacy
Ibuprofen $200 \mathrm{mg}+$ caffeine $200 \mathrm{mg}, \mathrm{n}=29$ for efficacy
Ibuprofen $200 \mathrm{mg}, \mathrm{n}=31$ for efficacy
Ibuprofen $400 \mathrm{mg}, \mathrm{n}=30$ for efficacy
Placebo, $\mathrm{n}=11$ for efficacy

Outcomes Pl: standard 4-point scale, an 8-word scale (randomly placed words ranging from 'no pain' to 'excruciating', scored 0 - 7), and a $100 \mathrm{~mm}$ VAS

PR: standard 5-point scale and a $100 \mathrm{~mm}$ VAS

PGE: standard 5-point scale

Withdrawals and dropouts

Serious adverse events

Notes $\quad$ Oxford Quality Score: R2, DB2, W1. Total = 5

\section{Risk of bias}

\begin{tabular}{lll}
\hline Bias & Authors' judgement & Support for judgement \\
\hline $\begin{array}{l}\text { Random sequence genera- } \\
\text { tion (selection bias) }\end{array}$ & Low risk & Randomised using a random number computer program \\
\hline $\begin{array}{l}\text { Allocation concealment } \\
\text { (selection bias) }\end{array}$ & Low risk & Remote packaging, labelled only with treatment number \\
\hline $\begin{array}{l}\text { Blinding of participants } \\
\text { and personnel (perfor- } \\
\text { mance bias) } \\
\text { All outcomes }\end{array}$ & Low risk & "identical matching capsules" \\
\hline Size & High risk & $<50$ participants in relevant treatment groups \\
\hline
\end{tabular}


Sunshine 1996

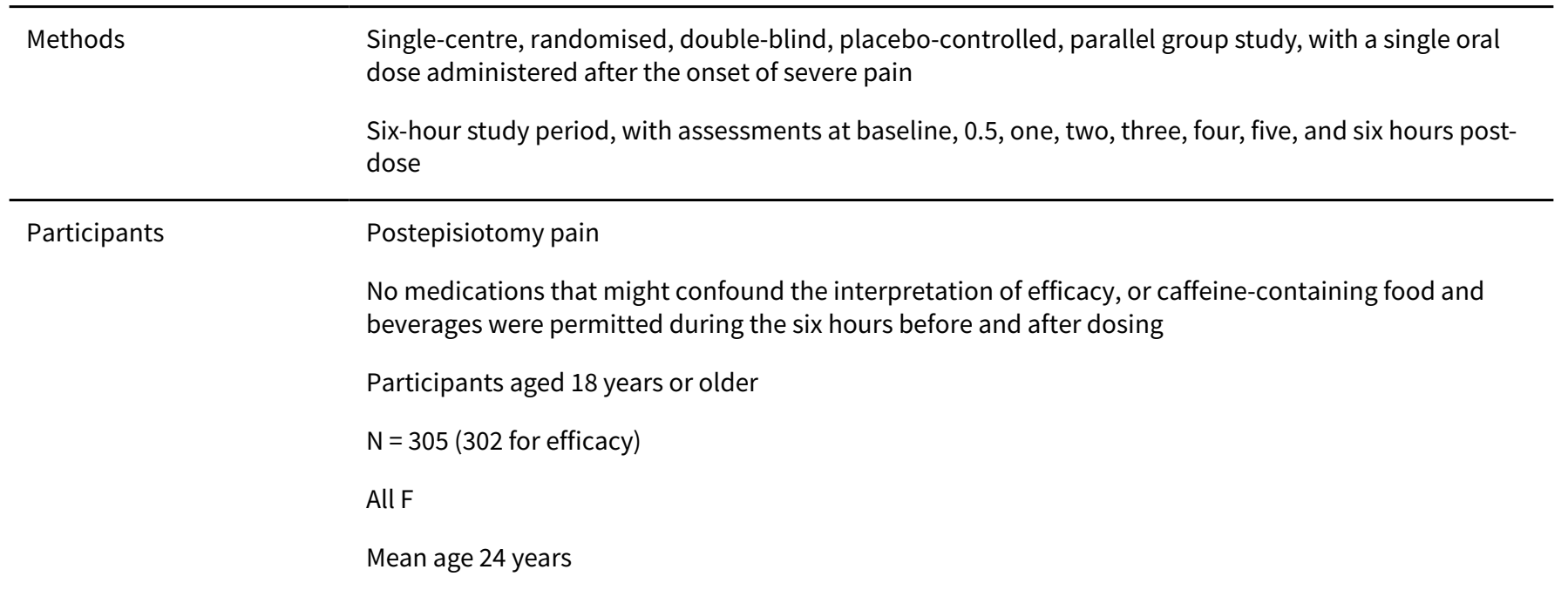

\begin{tabular}{ll}
\hline Interventions & Ibuprofen $100 \mathrm{mg}+$ caffeine $100 \mathrm{mg}, \mathrm{n}=50$ \\
& Ibuprofen $100 \mathrm{mg}, \mathrm{n}=51$ \\
& Ibuprofen $200 \mathrm{mg}+$ caffeine $100 \mathrm{mg}, \mathrm{n}=50$ \\
& Ibuprofen $200 \mathrm{mg}, \mathrm{n}=50$ \\
& Ibuprofen $50 \mathrm{mg}, \mathrm{n}=51$ \\
& Placebo, $\mathrm{n}=50$
\end{tabular}

PI: standard 4-point scale
PR: standard 5-point scale
PGE: 4-point categorical scale (0= poor, $1=$ fair, $2=$ good, $3=$ excellent)
Withdrawals and dropouts
Serious adverse events

Notes Oxford Quality Score: R1, DB2, W1. Total = 4

\section{Risk of bias}

\begin{tabular}{lll}
\hline Bias & Authors' judgement & Support for judgement \\
\hline $\begin{array}{l}\text { Random sequence genera- } \\
\text { tion (selection bias) }\end{array}$ & Unclear risk & Not reported \\
\hline $\begin{array}{l}\text { Allocation concealment } \\
\text { (selection bias) }\end{array}$ & Unclear risk & Not reported \\
\hline $\begin{array}{l}\text { Blinding of participants } \\
\text { and personnel (perfor- } \\
\text { mance bias) } \\
\text { All outcomes }\end{array}$ & Low risk & "All medications were dispensed as capsules" \\
\hline Size & & \\
\hline
\end{tabular}


DB: double-blind; F: female; $\mathrm{N}$ - number of participants in study; n: number of participants in treatment arm; PGE: Patient Global Evaluation of treatment; PI: pain intensity; PR: pain relief; R: randomised; VAS: visual analogue scale

Characteristics of studies awaiting assessment [ordered by study ID]

NCT01929031

\begin{tabular}{|c|c|}
\hline Methods & Randomised, double-blind, placebo-controlled, parallel group study \\
\hline Participants & $\begin{array}{l}\text { Surgical extraction of } 3 \text { - } 4 \text { impacted third molar(s), with a minimum of two mandibular extractions } \\
\text { Age: } 18-55 \text { years } \\
\text { Pain } \geq 5 / 10 \text { within } 4.5 \text { hours of end of surgery } \\
N=561\end{array}$ \\
\hline Interventions & $\begin{array}{l}\text { Ibuprofen } 400 \mathrm{mg}+\text { caffeine } 100 \mathrm{mg} \\
\text { Ibuprofen } 400 \mathrm{mg} \\
\text { Caffeine } 100 \mathrm{mg} \\
\text { Placebo }\end{array}$ \\
\hline Outcomes & $\begin{array}{l}\text { Time-weighted sum of pain relief (PAR) and pain intensity difference (PID) from } 0 \text { to } 8 \text { hours } \\
\text { (SPRID0-8h) } \\
2 \text { hours SPRID } \\
\text { Time to rescue } \\
\text { Time to meaningful relief }\end{array}$ \\
\hline Notes & Completed March 2014 but results not yet available \\
\hline
\end{tabular}

$\mathrm{N}$ : number of participants in study

\section{DATA AND ANALYSES}

Comparison 1. Ibuprofen $200 \mathrm{mg}+$ caffeine $\mathbf{1 0 0} \mathrm{mg}$ versus placebo

\begin{tabular}{lllll}
\hline Outcome or subgroup title & No. of studies & $\begin{array}{l}\text { No. of partici- } \\
\text { pants }\end{array}$ & Statistical method & Effect size \\
\hline $\begin{array}{l}1 \text { At least 50\% of maximum } \\
\text { pain relief }\end{array}$ & 4 & 334 & Risk Ratio (M-H, Fixed, 95\% Cl) & $5.51[3.48,8.72]$ \\
\hline 2 Remedication & 3 & 293 & Risk Ratio (M-H, Fixed, 95\% Cl) & $0.46[0.35,0.60]$ \\
\hline 3 Adverse events & 4 & 336 & Risk Ratio (M-H, Fixed, 95\% Cl) & $1.86[0.91,3.79]$ \\
\hline
\end{tabular}

Analysis 1.1. Comparison $1 \mathrm{lbuprofen} 200 \mathrm{mg}+$ caffeine $100 \mathrm{mg}$ versus placebo, Outcome 1 At least $50 \%$ of maximum pain relief.

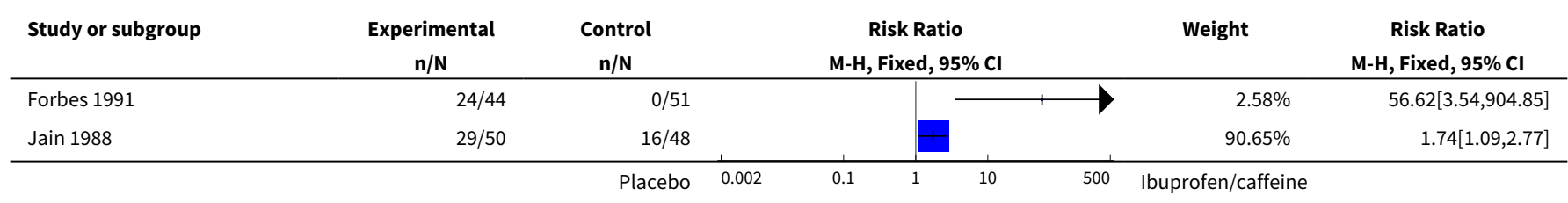




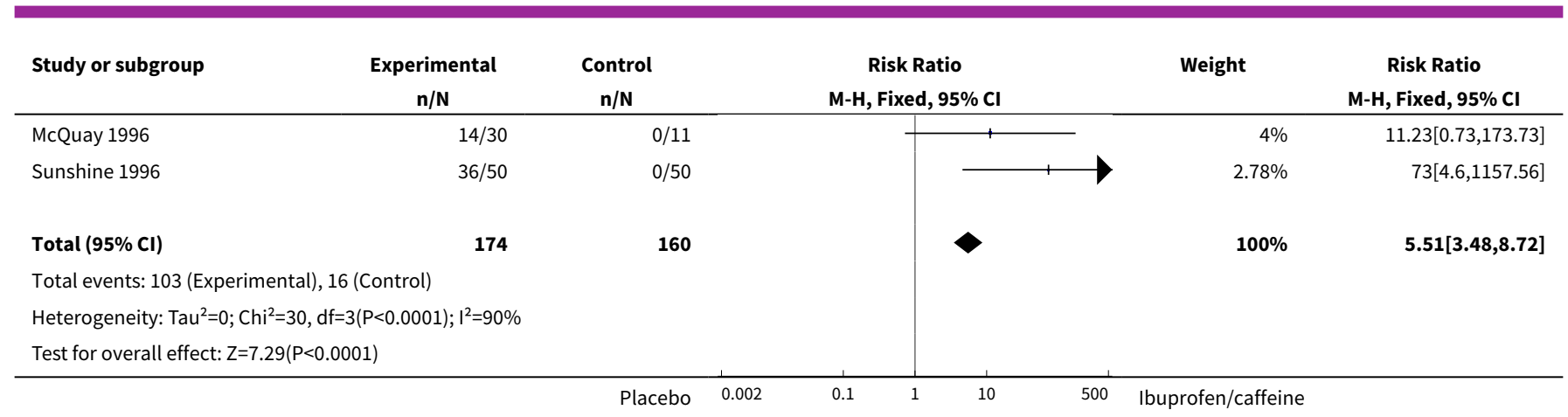

\section{Analysis 1.2. Comparison $1 \mathrm{lbuprofen} 200 \mathrm{mg}+$ caffeine $100 \mathrm{mg}$ versus placebo, Outcome 2 Remedication.}

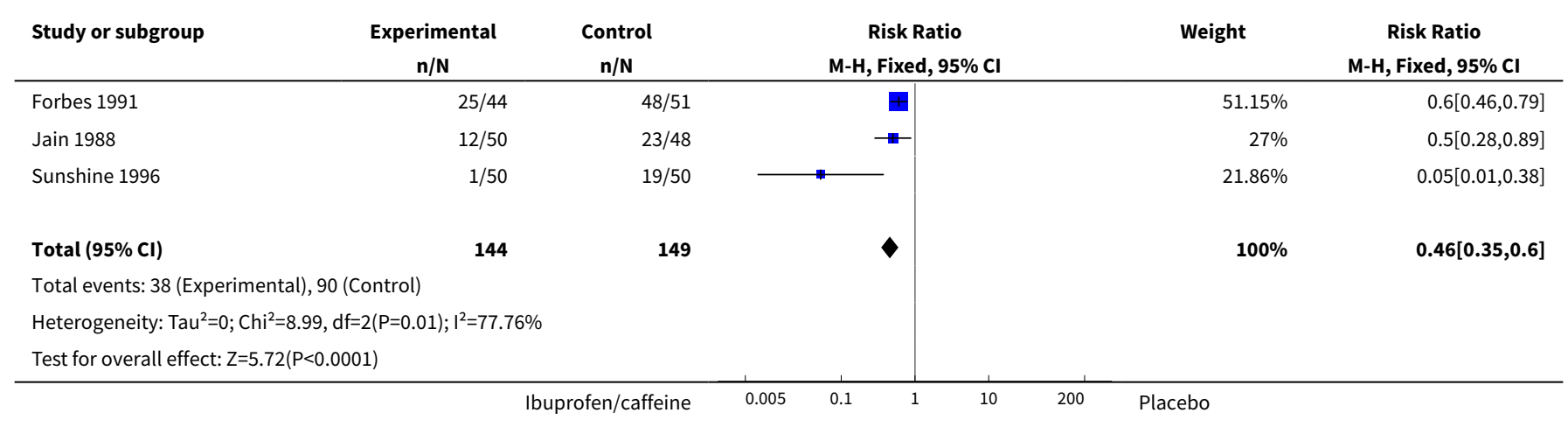

Analysis 1.3. Comparison 1 lbuprofen $200 \mathrm{mg}+$ caffeine $100 \mathrm{mg}$ versus placebo, Outcome 3 Adverse events.

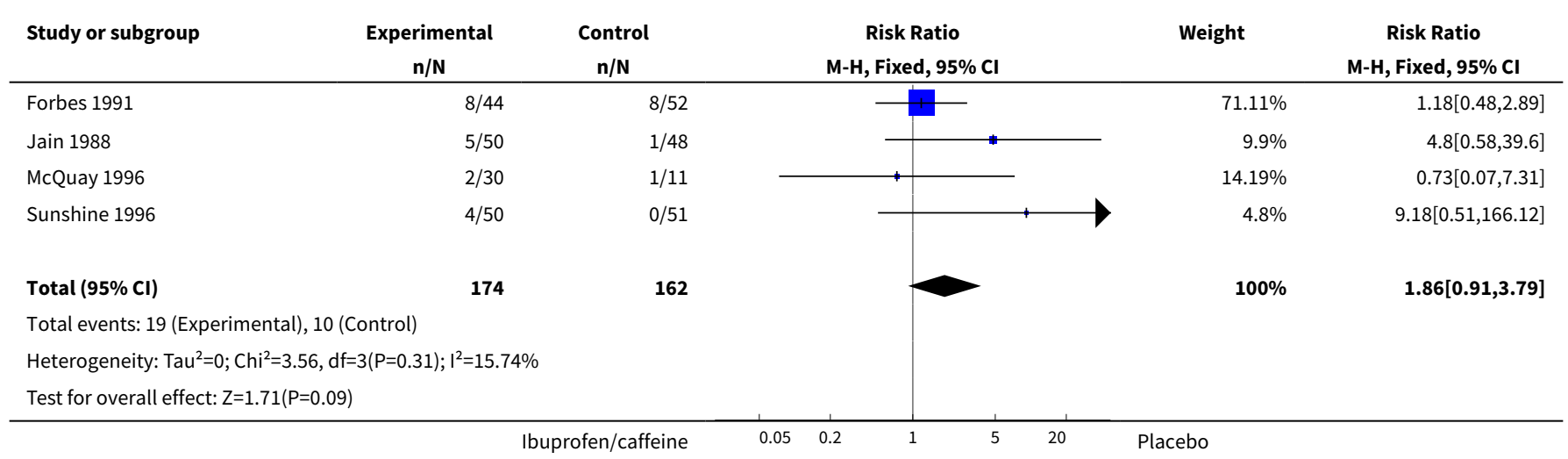

Comparison 2. Ibuprofen $100 \mathrm{mg}+$ caffeine $100 \mathrm{mg}$ versus placebo

\begin{tabular}{lllll}
\hline Outcome or subgroup title & No. of studies & $\begin{array}{l}\text { No. of partici- } \\
\text { pants }\end{array}$ & Statistical method & Effect size \\
\hline $\begin{array}{l}1 \text { At least } 50 \% \text { of maximum } \\
\text { pain relief }\end{array}$ & 2 & 200 & Risk Ratio (M-H, Fixed, 95\% Cl) & 44.82 [6.29, 319.49] \\
\hline
\end{tabular}




\begin{tabular}{lllll}
\hline Outcome or subgroup title & No. of studies & $\begin{array}{l}\text { No. of partici- } \\
\text { pants }\end{array}$ & Statistical method & Effect size \\
\hline 2 Remedication & 2 & 200 & Risk Ratio (M-H, Fixed, 95\% Cl) & $0.53[0.41,0.67]$ \\
\hline 3 Adverse events & 2 & 201 & Risk Ratio (M-H, Fixed, 95\% Cl) & $1.80[0.83,3.90]$ \\
\hline
\end{tabular}

Analysis 2.1. Comparison 2 Ibuprofen $100 \mathrm{mg}+$ caffeine $100 \mathrm{mg}$ versus placebo, Outcome 1 At least $50 \%$ of maximum pain relief.

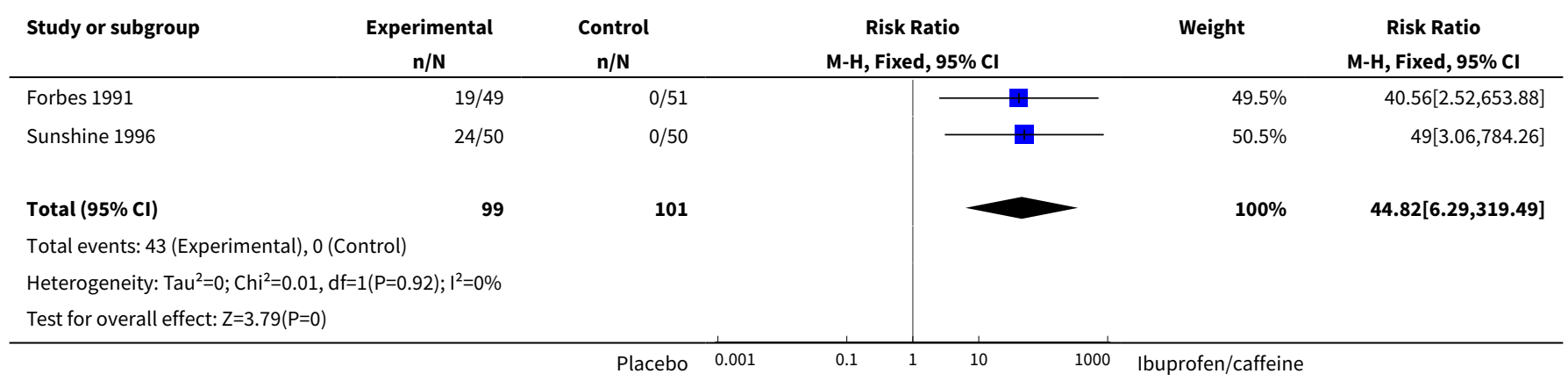

Analysis 2.2. Comparison 2 Ibuprofen $100 \mathrm{mg}+$ caffeine $100 \mathrm{mg}$ versus placebo, Outcome 2 Remedication.

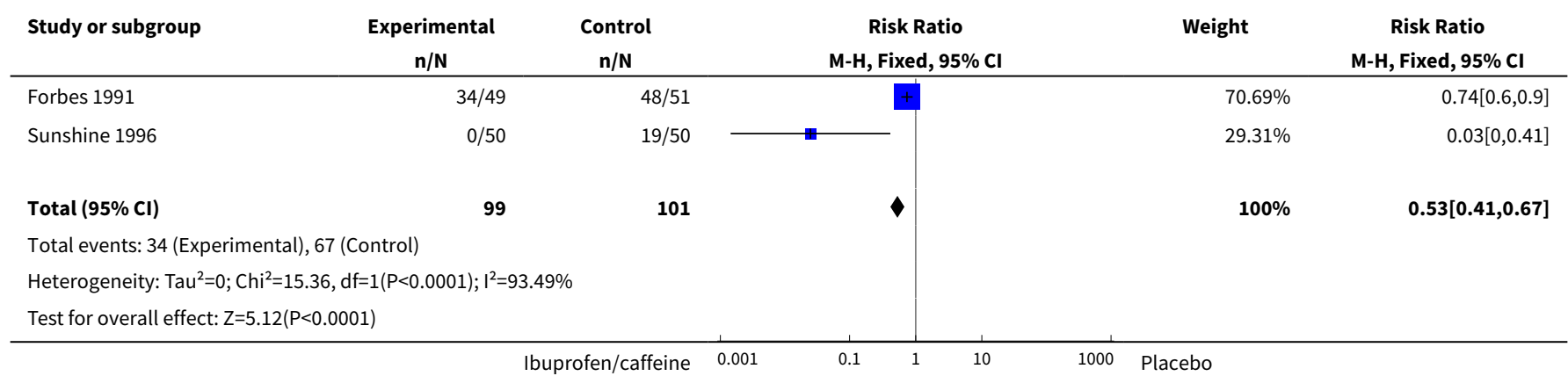

Analysis 2.3. Comparison 2 lbuprofen $100 \mathrm{mg}+$ caffeine $100 \mathrm{mg}$ versus placebo, Outcome 3 Adverse events.

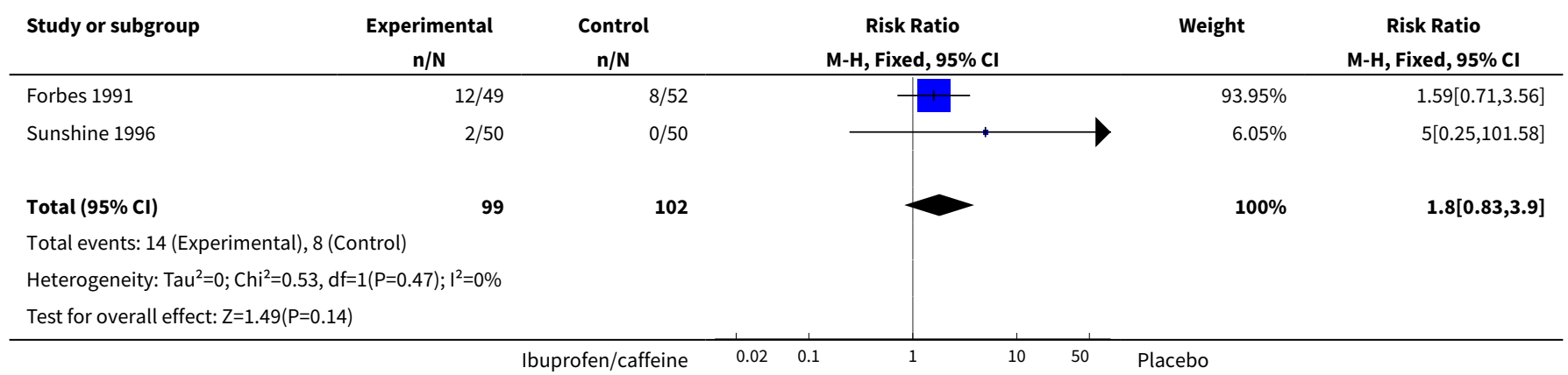




\section{AP PEN DICES}

\section{Appendix 1. Search strategy for CENTRAL}

1. MeSH descriptor: Ibuprofen this term only

2. (ibuprofen or brufen or propionic acid or "isobutylphenyl propionic acid")

3. MeSH descriptor: Caffeine this term only

4. Caffeine:ti,ab,kw

5. 1 or 2

6. 3 or 4

7. 5 and 6

8. MeSH descriptor: Pain, Postoperative this term only

9. ((postoperative near/4 pain ${ }^{\star}$ ) or (post-operative near/4 pain $\left.{ }^{\star}\right)$ or (post-operative-pain ${ }^{\star}$ ) or (post ${ }^{\star}$ near/4 pain ${ }^{\star}$ ) or (postoperative near/4 analgesi ${ }^{\star}$ ) or (post-operative near/4 analgesi ${ }^{\star}$ ) or ("post-operative analgesi*")):ti,ab,kw

10.((post-surgical near/4 pain*) or ("post surgical" near/4 pain $\left.{ }^{\star}\right)$ or (post-surgery near/4 pain*)):ti,ab,kw

11.("pain-relief after surg*" or "pain following surg*" or "pain control after"):ti,ab,kw

12.(("post surg*" or post-surg*) and (pain* or discomfort)):ti,ab,kw

13. ((pain* near/4 "after surg*") or (pain* near/4 "after operat"

14. ((analgesi* near/4 "after surg $\left.{ }^{\star} "\right)$ or (analgesi ${ }^{\star}$ near/4 "after operat ${ }^{\star}$ ) or (analgesi* near/4 "follow* operat*") or (analgesi ${ }^{\star}$ near/4 "follow* surg*")):ti,ab,kw

15.MeSH descriptor: Surgical Procedures, Operative explode all trees

16.8 or 9 or 10 or 11 or 12 or 13 or 14 or 15

17.7 and 16

\section{Appendix 2. Search strategy for MEDLINE (via OVID)}

1. Ibuprofen/ or (ibuprofen or brufen or propionic acid or isobutylphenyl propionic acid).mp.

2. Caffeine/ or caffeine.mp.

3. 1 and 2

4. Pain, Postoperative/

5. ((postoperative adj4 pain $\left.{ }^{\star}\right)$ or (post-operative adj4 pain ${ }^{\star}$ ) or post-operative-pain ${ }^{\star}$ or (post* adj4 pain ${ }^{\star}$ ) or (postoperative adj4 analgesi ${ }^{\star}$ ) or (post-operative adj4 analgesi ${ }^{\star}$ ) or "post-operative analgesi $\left.{ }^{\star} "\right) . m p$.

6. ((post-surgical adj4 pain*) or ("post surgical" adj4 pain*) or (post-surgery adj4 pain*)).mp.

7. ("pain-relief after surg*" or "pain following surg*" or "pain control after").mp.

8. (("post surg*" or post-surg*) and (pain* or discomfort)).mp.

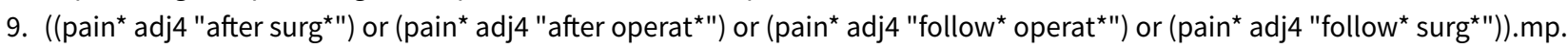

10.((analgesi* adj4 "after surg*") or (analgesi* adj4 "after operat*") or (analgesi* adj4 "follow* operat*") or (analgesi" adj4 "follow* surg*")).mp.

11.exp Surgical Procedures, Operative/

12.or/4-11

13.3 and 12

14. randomized controlled trial.pt.

15.controlled clinical trial.pt.

16.randomized.ab.

17. placebo.ab.

18.drug therapy.fs.

19.randomly.ab.

20.trial.ab.

21.groups.ab.

22.14 or 15 or 16 or 17 or 18 or 19 or 20 or 21

23.exp animals/ not humans.sh.

24.22 not 23

25.13 and 24

Single dose oral ibuprofen plus caffeine for acute postoperative pain in adults (Review)

Copyright $\odot 2019$ The Cochrane Collaboration. Published by John Wiley \& Sons, Ltd. 


\section{Appendix 3. Search strategy for EMBASE (via Ovid)}

1. Ibuprofen/ or (ibuprofen or brufen or propionic acid or isobutylphenyl propionic acid).mp.

2. Caffeine/ or caffeine.mp.

3. 1 and 2

4. Pain, Postoperative/

5. ((postoperative adj4 pain $\left.{ }^{\star}\right)$ or (post-operative adj4 pain $\left.{ }^{\star}\right)$ or post-operative-pain* or (post ${ }^{\star}$ adj4 pain ${ }^{\star}$ ) or (postoperative adj4 analgesi ${ }^{\star}$ ) or (post-operative adj4 analgesi*) or "post-operative analgesi*").mp.

6. ((post-surgical adj4 pain*) or ("post surgical" adj4 pain*) or (post-surgery adj4 pain*)).mp.

7. ("pain-relief after surg*" or "pain following surg*" or "pain control after").mp.

8. (("post surg*" or post-surg*) and (pain* or discomfort)).mp.

9. ((pain* adj4 "after surg*") or (pain* adj4 "after operat*") or (pain* adj4 "follow* operat*") or (pain* adj4 "follow* surg*")).mp.

10.((analgesi* adj4 "after surg*") or (analgesi* adj4 "after operat") or (analgesi* adj4 "follow* operat*") or (analgesi* adj4 "follow* surg*")).mp.

11.exp Surgical Procedures, Operative/

12.or/4-11

13.3 and 12

14.random*.tw.

15. factorial ${ }^{\star}$.tw.

16. crossover ${ }^{\star}$.tw.

17. cross over ${ }^{\star}$.tw.

18. cross-over ${ }^{\star}$.tw.

19. placebo*.tw.

20. $\left(\right.$ doubl $^{\star}$ adj blind $\left.{ }^{\star}\right)$.tw.

21. (singl ${ }^{\star}$ adj blind $\left.{ }^{\star}\right)$.tw.

22. assign ${ }^{\star}$.tw.

23. allocat ${ }^{\star}$.tw.

24.volunteer ${ }^{\star}$.tw.

25.Crossover Procedure/

26.double-blind procedure.tw.

27.Randomized Controlled Trial/

28.Single Blind Procedure/

29. or/14-28

30.13 and 29

\section{Appendix 4. Glossary}

Categorical rating scale: The commonest is the five-category scale (none, slight, moderate, good or lots, and complete). For analysis, numbers are given to the verbal categories (for pain intensity, none $=0$, mild $=1$, moderate $=2$ and severe $=3$, and for relief none $=0$, slight $=1$, moderate $=2$, good or lots $=3$ and complete $=4$ ). Data from different subjects is then combined to produce means (rarely medians) and measures of dispersion (usually standard errors of means). The validity of converting categories into numerical scores was checked by comparison with concurrent visual analogue scale measurements. Good correlation was found, especially between pain relief scales using cross-modality matching techniques. Results are usually reported as continuous data, mean or median pain relief or intensity. Few studies present results as discrete data, giving the number of participants who report a certain level of pain intensity or relief at any given assessment point. The main advantages of the categorical scales are that they are quick and simple. The small number of descriptors may force the scorer to choose a particular category when none describes the pain satisfactorily.

Visual analogue scale (VAS): For pain intensity, lines with left end labelled "no pain" and right end labelled "worst pain imaginable", and for pain relief lines with left end labelled "no relief of pain" and right end labelled "complete relief of pain", seem to overcome the limitation of forcing patient descriptors into particular categories. Patients mark the line at the point which corresponds to their pain or pain relief. The scores are obtained by measuring the distance between the no relief end and the patient's mark, usually in millimetres. The main advantages of VAS are that they are simple and quick to score, avoid imprecise descriptive terms and provide many points from which to choose. More concentration and co-ordination are needed, which can be difficult postoperatively or with neurological disorders.

Total pain relief (TOTPAR): TOTPAR is calculated as the sum of pain relief scores over a period of time. If a patient had complete pain relief immediately after taking an analgesic, and maintained that level of pain relief for six hours, they would have a six-hour TOTPAR of the maximum of 24. Differences between pain relief values at the start and end of a measurement period are dealt with by the trapezoidal 
rule. This is a simple method that approximately calculates the definite integral of the area under the pain relief curve by calculating the sum of the areas of several trapezoids that together closely approximate to the area under the curve.

Summed pain intensity difference (SPID): SPID is calculated as the sum of the differences between the pain scores and baseline pain score over a period of time. Differences between pain intensity values at the start and end of a measurement period are dealt with by the trapezoidal rule.

VAS TOTPAR and VAS SPID are visual analogue versions of TOTPAR and SPID.

See "Measuring pain" in Bandolier's Little Book of Pain (Moore 2003).

Appendix 5. Results for individual studies: efficacy

\begin{tabular}{|c|c|c|c|c|c|c|}
\hline Study ID & Condition & Treatment & $\begin{array}{l}\text { Efficacy out- } \\
\text { come }\end{array}$ & $\begin{array}{l}\text { Participants } \\
\text { with outcome }\end{array}$ & $\begin{array}{l}\text { Remedica- } \\
\text { tion }\end{array}$ & $\begin{array}{l}\text { Time to } \\
\text { remedica- } \\
\text { tion }(h)\end{array}$ \\
\hline $\begin{array}{l}\text { Forbes } \\
1991\end{array}$ & Dental & $\begin{array}{l}\text { (1) Ibuprofen } 100 \mathrm{mg}+\text { caffeine } 100 \\
\mathrm{mg}, \mathrm{n}=49 \\
\text { (2) Ibuprofen } 100 \mathrm{mg}, \mathrm{n}=49 \\
\text { (3) Ibuprofen } 200 \mathrm{mg}+\text { caffeine } 100 \\
\mathrm{mg}, \mathrm{n}=44 \\
\text { (4) Ibuprofen } 200 \mathrm{mg}, \mathrm{n}=48 \\
\text { (5) Placebo, } \mathrm{n}=51\end{array}$ & $\begin{array}{l}\text { TOTPAR } 6 \\
\text { hours: } \\
\text { (1) } 8.95 \\
\text { (2) } 6.67 \\
\text { (3) } 12.1 \\
\text { (4) } 8.65 \\
\text { (5) } 2.21\end{array}$ & $\begin{array}{l}\geq 50 \% \text { max PR: } \\
\text { (1) } 19 / 49 \\
\text { (2) } 13 / 49 \\
\text { (3) } 24 / 44 \\
\text { (4) } 17 / 48 \\
\text { (5) } 0 / 51\end{array}$ & $\begin{array}{l}\text { By } 8 \text { hours } \\
\text { (1) } 34 / 49 \\
\text { (2) } 38 / 49 \\
\text { (3) } 25 / 44 \\
\text { (4) } 38 / 48 \\
\text { (5) } 48 / 51\end{array}$ & $\begin{array}{l}\text { Mean: } \\
\text { (1) } 5.4 \\
\text { (2) } 4.8 \\
\text { (3) } 6.1 \\
\text { (4) } 5.1 \\
\text { (5) } 3.0 \\
\text { Note } \\
\text { remedica- } \\
\text { tion after } 8 \\
\text { hours cen- } \\
\text { sored at } 8 \\
\text { hours }\end{array}$ \\
\hline
\end{tabular}

\begin{tabular}{|c|c|c|c|c|c|c|}
\hline Jain 1988 & $\begin{array}{l}\text { Postepi- } \\
\text { siotomy }\end{array}$ & $\begin{array}{l}\text { (1) Ibuprofen } 200 \mathrm{mg}+\text { caffeine } 100 \\
\mathrm{mg}, \mathrm{n}=50 \\
\text { (2) Ibuprofen } 400 \mathrm{mg}, \mathrm{n}=49 \\
\text { (3) Placebo, } \mathrm{n}=48\end{array}$ & $\begin{array}{l}\text { TOTPAR } 6 \\
\text { hours: } \\
\text { (1) } 13.9 \\
\text { (2) } 14.4 \\
\text { (3) } 8.6\end{array}$ & $\begin{array}{l}\text { (1) } 29 / 50 \\
\text { (2) } 30 / 49 \\
\text { (3) } 16 / 48\end{array}$ & $\begin{array}{l}\text { (1) } 12 / 50 \\
\text { (2) } 10 / 49 \\
\text { (3) } 23 / 48\end{array}$ & No data \\
\hline $\begin{array}{l}\text { McQuay } \\
1996\end{array}$ & Dental & $\begin{array}{l}\text { (1) Ibuprofen } 200 \mathrm{mg}+\text { caffeine } 50 \\
\mathrm{mg}, \mathrm{n}=30 \\
\text { (2) Ibuprofen } 200 \mathrm{mg}+\text { caffeine } 100 \\
\mathrm{mg}, \mathrm{n}=30 \\
\text { (3) Ibuprofen } 200 \mathrm{mg}+\text { caffeine } 200 \\
\mathrm{mg}, \mathrm{n}=29 \\
\text { (4) Ibuprofen } 200 \mathrm{mg}, \mathrm{n}=31 \\
\text { (5) Ibuprofen } 400 \mathrm{mg}, \mathrm{n}=30 \\
\text { (6) Placebo, } \mathrm{n}=11\end{array}$ & $\begin{array}{l}\text { TOTPAR } 6 \\
\text { hours: } \\
\text { (1) } 7.0 \\
\text { (2) } 10.3 \\
\text { (3) } 9.5 \\
\text { (4) } 3.0 \\
\text { (5) } 5.5 \\
\text { (6) } 0\end{array}$ & $\begin{array}{l}\geq 50 \% \text { max PR: } \\
\text { (1) } 8 / 30 \\
\text { (2) } 14 / 30 \\
\text { (3) } 12 / 29 \\
\text { (4) } 2 / 31 \\
\text { (5) } 5 / 30 \\
\text { (6) } 0 / 11\end{array}$ & No data & No data \\
\hline $\begin{array}{l}\text { Sunshine } \\
1996\end{array}$ & $\begin{array}{l}\text { Postepi- } \\
\text { siotomy }\end{array}$ & $\begin{array}{l}\text { (1) Ibuprofen } 100 \mathrm{mg}+\text { caffeine } 100 \\
\mathrm{mg}, \mathrm{n}=50 \\
\text { (2) Ibuprofen } 100 \mathrm{mg}, \mathrm{n}=51 \\
\text { (3) Ibuprofen } 200 \mathrm{mg}+\text { caffeine } 100 \\
\mathrm{mg}, \mathrm{n}=50 \\
\text { (4) Ibuprofen } 200 \mathrm{mg}, \mathrm{n}=50 \\
\text { (5) Placebo, } \mathrm{n}=50\end{array}$ & $\begin{array}{l}\text { TOTPAR } 6 \\
\text { hours: } \\
\text { (1) } 10.9 \\
\text { (2) } 8.2 \\
\text { (3) } 14.9 \\
\text { (4) } 13.9 \\
\text { (5) } 2.2\end{array}$ & $\begin{array}{l}\geq 50 \% \text { max PR: } \\
\text { (1) } 24 / 50 \\
\text { (2) } 17 / 51 \\
\text { (3) } 36 / 50 \\
\text { (4) } 33 / 50 \\
\text { (5) } 0 / 50\end{array}$ & $\begin{array}{l}\text { (1) } 0 / 50 \\
\text { (2) } 0 / 51 \\
\text { (3) } 1 / 50 \\
\text { (4) } 0 / 50 \\
\text { (5) } 19 / 51\end{array}$ & No data \\
\hline
\end{tabular}

PR: pain relief; TOTPAR: total pain relief 


\section{Appendix 6. Results for individual studies: adverse events}

\begin{tabular}{|c|c|c|c|c|}
\hline Study ID & Condition & Treatment & $\begin{array}{l}\text { Any adverse } \\
\text { events }\end{array}$ & $\begin{array}{l}\text { Serious adverse } \\
\text { events }\end{array}$ \\
\hline Forbes 1991 & Dental & $\begin{array}{l}\text { (1) Ibuprofen } 100 \mathrm{mg}+\text { caffeine } 100 \mathrm{mg}, \mathrm{n}=49 \\
\text { (2) Ibuprofen } 100 \mathrm{mg}, \mathrm{n}=49 \\
\text { (3) Ibuprofen } 200 \mathrm{mg}+\text { caffeine } 100 \mathrm{mg}, \mathrm{n}=44 \\
\text { (4) Ibuprofen } 200 \mathrm{mg}, \mathrm{n}=48 \\
\text { (5) Placebo, } \mathrm{n}=51\end{array}$ & $\begin{array}{l}\text { (1) } 12 / 49 \\
\text { (2) } 5 / 49 \\
\text { (3) } 8 / 44 \\
\text { (4) } 6 / 48 \\
\text { (5) } 8 / 52\end{array}$ & None \\
\hline Jain 1988 & Postepisiotomy & $\begin{array}{l}\text { Ibuprofen } 200 \mathrm{mg}+\text { caffeine } 100 \mathrm{mg}, \mathrm{n}=50 \\
\text { Ibuprofen } 400 \mathrm{mg}, \mathrm{n}=49 \\
\text { Placebo, } \mathrm{n}=48\end{array}$ & $\begin{array}{l}\text { (1) } 5 / 50 \\
\text { (2) } 2 / 49 \\
\text { (3) } 1 / 48\end{array}$ & Not mentioned \\
\hline McQuay 1996 & Dental & $\begin{array}{l}\text { (1) Ibuprofen } 200 \mathrm{mg}+\text { caffeine } 50 \mathrm{mg}, \mathrm{n}=30 \\
\text { (2) Ibuprofen } 200 \mathrm{mg}+\text { caffeine } 100 \mathrm{mg}, \mathrm{n}=30 \\
\text { (3) Ibuprofen } 200 \mathrm{mg}+\text { caffeine } 200 \mathrm{mg}, \mathrm{n}=29 \\
\text { (4) Ibuprofen } 200 \mathrm{mg}, \mathrm{n}=31 \\
\text { (5) Ibuprofen } 400 \mathrm{mg}, \mathrm{n}=30 \\
\text { (6) Placebo, } \mathrm{n}=11\end{array}$ & $\begin{array}{l}\text { (1) } 1 / 30 \\
\text { (2) } 2 / 30 \\
\text { (3) } 0 / 29 \\
\text { (4) } 4 / 31 \\
\text { (5) } 2 / 30 \\
\text { (6) } 1 / 11\end{array}$ & None \\
\hline Sunshine 1996 & Postepisiotomy & $\begin{array}{l}\text { (1) Ibuprofen } 100 \mathrm{mg}+\text { caffeine } 100 \mathrm{mg}, \mathrm{n}=50 \\
\text { (2) Ibuprofen } 100 \mathrm{mg}, \mathrm{n}=51 \\
\text { (3) Ibuprofen } 200 \mathrm{mg}+\text { caffeine } 100 \mathrm{mg}, \mathrm{n}=50 \\
\text { (4) Ibuprofen } 200 \mathrm{mg}, \mathrm{n}=50 \\
\text { (5) Placebo, } \mathrm{n}=50\end{array}$ & $\begin{array}{l}\text { (1) } 2 / 50 \\
\text { (2) } 4 / 51 \\
\text { (3) } 4 / 50 \\
\text { (4) } 1 / 50 \\
\text { (5) } 0 / 51\end{array}$ & None \\
\hline
\end{tabular}

\section{WHAT'S NEW}

\begin{tabular}{lll}
\hline Date & Event & Description \\
\hline 29 May 2019 & Amended & Contact details updated. \\
\hline 11 October 2017 & Review declared as stable & No new studies likely to change the conclusions are expected. \\
\hline
\end{tabular}

\section{H I S T O R Y}

Protocol first published: Issue 2, 2015

Review first published: Issue 7, 2015

\begin{tabular}{lll}
\hline Date & Event & Description \\
\hline 27 February 2017 & Review declared as stable & See Published notes. \\
\hline
\end{tabular}




\section{CONTRIBUTIONS OF AUTHORS}

SD and RAM wrote the protocol. RAM and SD carried out searches, assessed studies for inclusion, and extracted data. PW acted as arbitrator. All authors were involved in writing the review. RAM will be responsible for updating the review.

\section{DECLARATIONS OF INTEREST}

SD has no conflicts relating to this review or any similar product.

PW has no conflicts relating to this review or any similar product.

RAM has no conflicts relating to this review or any similar product.

For transparency, SD, PW, and RAM have received research support from charities, government, and industry sources at various times, but none relate to this review. SD, PW, and RAM are funded by the NIHR for work on a series of reviews informing the unmet need of chronic pain and providing the evidence for treatments of pain.

\section{SOURCES OF SUPPORT}

\section{Internal sources}

- Oxford Pain Relief Trust, UK.

General institutional support

\section{External sources}

- No sources of support supplied

\section{NOTES}

In February 2017, the review authors ran restricted searches and found one new study in clinicaltrials.gov (NCT01929031). They had been notified by the new study's authors in November 2016 that the first results were available online. The study uses a different dose of ibuprofen plus caffeine from that in the Cochrane review, and does not report data that easily allow calculation of the review's primary outcome. However, it does appear to confirm the findings.

The review authors have requested information that would allow calculation of the review's primary outcome, and will consider updating the review if that becomes available and is likely to change the conclusions. This review is currently considered up to date.

\section{N DEX TERMS}

\section{Medical Subject Headings (MeSH)}

Acute Pain [ ${ }^{*}$ drug therapy]; Analgesics, Non-Narcotic [ ${ }^{*}$ administration \& dosage] [adverse effects]; Caffeine [ ${ }^{*}$ administration \& dosage] [adverse effects]; Drug Combinations; Ibuprofen [ ${ }^{\star}$ administration \& dosage] [adverse effects]; Numbers Needed To Treat; Pain, Postoperative [ ${ }^{\star}$ drug therapy]; Randomized Controlled Trials as Topic

\section{MeSH check words}

Adult; Humans 